Alireza Sepahvand, Mitja Prelovšek, Ali Akbar Nazari Samani, Robert James Wasson. Solute transport and solutional denudation rate of carbonate karst in the semi-arid Zagros region (southwestern Iran). Journal of Cave and Karst Studies, v. 83, no. 3, p. 93-108. DOI:10.4311/2020ES0102

\title{
SOLUTE TRANSPORT AND SOLUTIONAL DENUDATION RATE OF CARBONATE KARST IN THE SEMI-ARID ZAGROS REGION (SOUTHWESTERN IRAN)
}

\author{
Alireza Sepahvand ${ }^{1}$, Mitja Prelovšek ${ }^{2, C}$, Ali Akbar Nazari Samani ${ }^{3}$, Robert James Wasson ${ }^{4}$
}

\begin{abstract}
We conducted a one-year-long study of solute load measured three times per month in three neighboring subwatersheds (Alashtar, Khorram Abad, and Biranshahr) located in the Karkheh River basin in the Zagros region of southwestern Iran. Research was focused on the chemical composition of water (solute load), karst denudation rate, spatial and temporal variability, as well as comparison of solute load with suspended load. Results show that Ca-Mg- $\mathrm{HCO}_{3}$ is the dominant water type that reflects the lithological characteristics of the catchment areas. Lack of seasonal fluctuation of solute load and absence of dilution during high water levels but evident seasonal course of discharge defines the highest solute flux during the annual maximum of discharge in spring months. The highest solute flux is related to flood events. High annual variation of $\mathrm{Na}^{+}$concentration compared to conservative $\mathrm{Cl}^{-}$as well as Chloro-Alkali indexes (CAI and CAI2) suggests that $\mathrm{Na}^{+}$adsorption and desorption during ion-exchange reactions occur in the regolith. This $\mathrm{Na}^{+}$ variability, to some extent, explains weak $\mathrm{Ca}^{2+}$ and $\mathrm{Mg}^{2+}$ dilution effect during high water levels. During the measurement period (2014-2015), solute flux calculated per catchment area amounted to $49-69 \mathrm{t} \mathrm{km}^{-2} \mathrm{a}^{-1}$ (tons per km per year). The chemical composition of water and discharge shows by far the highest chemical denudation of limestones and dolomites (87-89\%), while dissolution of gypsum is of minor importance (11-13\%). As a result, the carbonate karst solutional denudation rate is between 0.010 and $0.040 \mathrm{~mm} \mathrm{a}^{-1}$, where the higher values are more probable for longer periods due to the relatively low discharge during the spring of 2015. Comparison of dissolved and suspended loads indicates that the transport of suspended load is an order of magnitude less than transport of the dissolved load; the only exception is one flash flood event when suspended load exceeded the dissolved load. Besides a small decrease in solute flux as well as carbonate karst dissolution rates from NW to SE, no large hydrochemical differences between the three subwatersheds were detected.
\end{abstract}

\section{INTRODUCTION}

Rock weathering and denudation are important processes in landscape evolution (Phillips, 2005; Borelli et al., 2007; Viles, 2012; Krautblatter and Moore, 2014; Krklec et al., 2016). Denudation, the weathering away of Earth's surface, is the combined action of chemical and mechanical processes. The style and rate of denudation reflects complex relationships between tectonic activity, lithology, climate, and surface processes (Ryb et al., 2014). With time, these denudation processes change the thickness of bedrock and soil, as well as their physical, hydrological, and chemical properties (Kieffer et al., 1999; Chesworth, 2008; Minasny et al., 2008; Molina Ballesteros et al., 2013; Krklec et al., 2016) resulting in a feed-back loop between soil depth and denudation rate (Heimsath et al., 1997).

Chemical denudation plays a significant role in karst geomorphic systems. It has received significant quantification, especially from the second half of the $19^{\text {th }}$ century. Such measurements, as well as their analysis and discussion, were strongly stimulated by Jeans Corbel's controversial conclusions in the 1950s. From analyses of thousands of field samples, he concluded that cold high mountains provide the most favorable environment for limestone dissolution, while hot regions have the lowest karst dissolution rates (Ford and Williams, 2007), which was in contrast with morphological evidence and conventional wisdom at the time.

Karst is a special style of landscape typically including leveled karst plains, enclosed depressions (dolines, cockpits, poljes) with conical hills, caves, and extensive underground water systems that are strongly influenced by chemical denudation of soluble rocks such as limestone, dolomite, marble, halite, and gypsum (Ford and Williams, 2007; Stokes et al., 2010). The unique features of karst landscapes are the effect of complex interactions between geology, climate, topography, hydrology, and biological factors over long time scales (Stokes et al., 2010). Carbonate karst landscapes occur worldwide, where carbonate rocks interact with fresh water, and cover $15.2 \%$ of the ice-free continental area (Goldscheider, 2020) and $11 \%$ (Raeisi, 2004) of Iran. Globally, 1.18 billion people (16.5\% of the global population) live on karst (Goldscheider, 2020) and nearly 20-25\% of the world population relies mostly or completely on karst aquifers

\footnotetext{
${ }^{1}$ Department of Range and Watershed Management Engineering, Faculty of Natural Resources and Agriculture,

Lorestan University, Khorramabad, Iran

${ }^{2}$ Karst Research Institute ZRC SAZU, Postojna, Slovenia, https://orcid.org/0000-0002-5415-0309;

${ }^{3}$ Department of Arid and Mountainous Regions Reclamation, Faculty of Natural Resources, University of Tehran, Iran

${ }^{4}$ College of Science and Engineering, James Cook University, Cairns, Australia.

ccorresponding author mitja.prelovsek@zrc-sazu.si
} 
(Ford and Williams, 2007); karst springs are important source of drinking and irrigation water in many subwatersheds of Iran (Ahmadipour, 1999).

Solution rates of carbonate minerals are several orders of magnitude higher than silicate minerals (Matsushi et al., 2010). Carbonate karst denudation rates can be measured using 5 main techniques OWhite, 2020): MEM, limestone tablets, hydrochemical, cosmogenic nuclides, and dated geomorphologic features. The MEM technique measures wall retreat using a portable rigid plate with a dial indicator seated on three steel studs imbedded into the rock. This technique is site-specific and can be used on bare rock only where subsoil dissolution is excluded. To get an insight into the overall dissolution rate in a catchment area, the hydrochemical method was used in this study. Since the bulk of dissolution takes place at the soil-bedrock contact, including epikarst (White, 2000), it is assumed that dissolved load measured by the hydrochemical approach mostly reflects surface lowering and relatively little is contributed by dissolution in vadose and phreatic zones. Some difficulties, constraints, and uncertainties of chemical denudation measurements in karst areas (e.g., surface of catchment area, extent of carbonate outcrop within catchment area, contribution of dissolved load by allogenic tributaries, dissolution of karst rocks overlain by protective caprock) have been presented in numerous papers internationally (White, 2000; Abu-Jaber et al., 2001; Krawczyk et al., 2003; Dixon and Thorn, 2005; Lauritzen, 2005; Gabrovšek, 2007, 2009; Kaufmann and Dreybrodt, 2007; Rzonca and Buczyński, 2013); in general, dissolution rates indicates a prevailing role of climate (runoff and soil $\mathrm{CO}_{2}$ concentration). Based on the empirical work of Smith and Atkinson (1976) on carbonate dissolution rates in the 1970's, comparison of denudation rates measured in the field and empirical calculations with a numerical model has been synthesized and analyzed by White (2000).

To improve global models of karst denudation, additional quantitative data from representative karst areas are needed and processes related to dissolution should be further studied. Therefore, the purpose of this paper is to estimate the current solute load, flux, and intensity of the chemical denudation process of carbonate rocks, as well as interpret the variability of controlling hydrochemical parameters in three subwatersheds in Lorestan province, Iran.

\section{STUDY AREA}

The study area (Khorram Abad, Biranshahr and Alashtar subwatersheds) covers a part of the Lorestan province located in the southwestern Iran (Fig. 1). They are part of the Karkheh River basin (Persian Gulf drainage basin) with general characteristics (area, extent of carbonate outcrops, total runoff) summarized in Table 1.

The study area is located between $33^{\circ} 11^{\prime} 47^{\prime \prime} \mathrm{N}$ and $34^{\circ} 03^{\prime} 27^{\prime \prime} \mathrm{N}$, and between $48^{\circ} 03^{\prime} 10^{\prime \prime} \mathrm{E}$ and $48^{\circ} 59^{\prime} 07^{\prime \prime} \mathrm{E}$. The subwatersheds are defined according to the positions of sampling sites, and cover an area of $3,576 \mathrm{~km}^{2}$. Elevation of the subwatersheds varies from 1,158 to 3,646 m a.s.l. (Fig. 2). Limestone and dolomite covers $1,262 \mathrm{~km}^{2}(35 \%)$, other carbonate rocks (mainly marls) $709 \mathrm{~km}^{2}(20 \%)$, Quaternary deposits (granular material of all grain sizes from pebbles to clay) $1,496 \mathrm{~km}^{2}$ (42\%), evaporites (gypsum, halite, marl) $14 \mathrm{~km}^{2}(0.4 \%)$, and non-carbonate non-Quaternary rocks (sandstone, siltstone, conglomerate with red chert, andesite, rhyodacite, and radiolarites) $95 \mathrm{~km}^{2}$ (3\%; Fig. 1). The upper part of the study area is mountainous, built mainly of Cretaceous and Miocene limestone, and the lower part is a plain with an old terrace formed on 25-150 m deep alluvial deposits (Ahmadipour, 2003; Fig. 2). The thickest carbonate sequences are in the Jurassic, Cretaceous, Miocene, and Oligocene rocks (Fig. 1). Dolomite can be found as beds in the Asmari Formation (Cucchi and Zini, 2003; Barmaki et al., 2019) and in thick carbonate deposits in the Triassic and Jurassic sequence. In the Zagros Mountains, the most extensive gypsum deposits are found in the Gachsaran Formation (Early Miocene), where gypsum makes up to two thirds of the stratigraphic sequence (Cucchi and Zini, 2003). Gypsum also occurs in the Aghajari Formation (stratigraphically located above the Gachsaran Formation), but due to uplift of the research area (Pusht-e-Kuh non-salt basin), the Gachsaran, as well as the Aghajari and Bakhtyari Formations, are either absent or are very poorly preserved (Bahroudi and Koyi 2004), and crop out only in a small area (14 $\left.\mathrm{km}^{2}\right)$ around the monitoring points of Alashtar and Khorram Abad subwatersheds. The most extensive halite deposits are found in the Hormoz Complex that was deposited during the Upper Precambrian to Middle Cambrian (Bosak et al., 1998); halite protrudes to the surface through the youngest formations as diapirs and, according to Mortazavi et al. (2017) and Nabavi and Agha Nabati (Aghanabati, 2004; Nabavi, 1976), extends at least several hundreds of kilometers SE of the research area (Bahroudi and Koyi, 2014). In the study area, the extent of the salt deposits of the Gachsaran Formation is of minor importance, covering only $0.01 \mathrm{~km}^{2}$ of the Khorram Abad subwatershed. From a structural point of view, the research area is located at the NE part of the Zagros Fold and Thrust Belt (Mohammadi and Field, 2009); the NE part of the Alashtar subwatershed is located on the Crushed Zone bordering the Sanandaj-Sirjan Metamorphic Zone.

Climate data for Khorram Abad, Kakasherf, Biranshahr, Chamangir, Doab Visian, Alashtar, Sif Abad, Dorod, Kakareza, Kahman, Nor Abad, Rimeleh, Borojerd, Sepid Dasht and Kohdasht meteorological stations for 1997-2015 (Alashtar), 1990-2015 (Khorram Abad) and 2006-2015 (Biranshahr) were used to produce a climatic summary. The climate of the study area ranges from semi-arid to slightly humid with an annual temperature oscillation from $-3.4^{\circ} \mathrm{C}$ during the wet season to $31.7^{\circ} \mathrm{C}$ during the dry season. The means of absolute minimum and maximum temperatures are $-15.1^{\circ} \mathrm{C}$ (January) and $42.9^{\circ} \mathrm{C}$ (July), respectively. The average annual amount of precipitation is $478 \mathrm{~mm}$ with a peak in winter that 

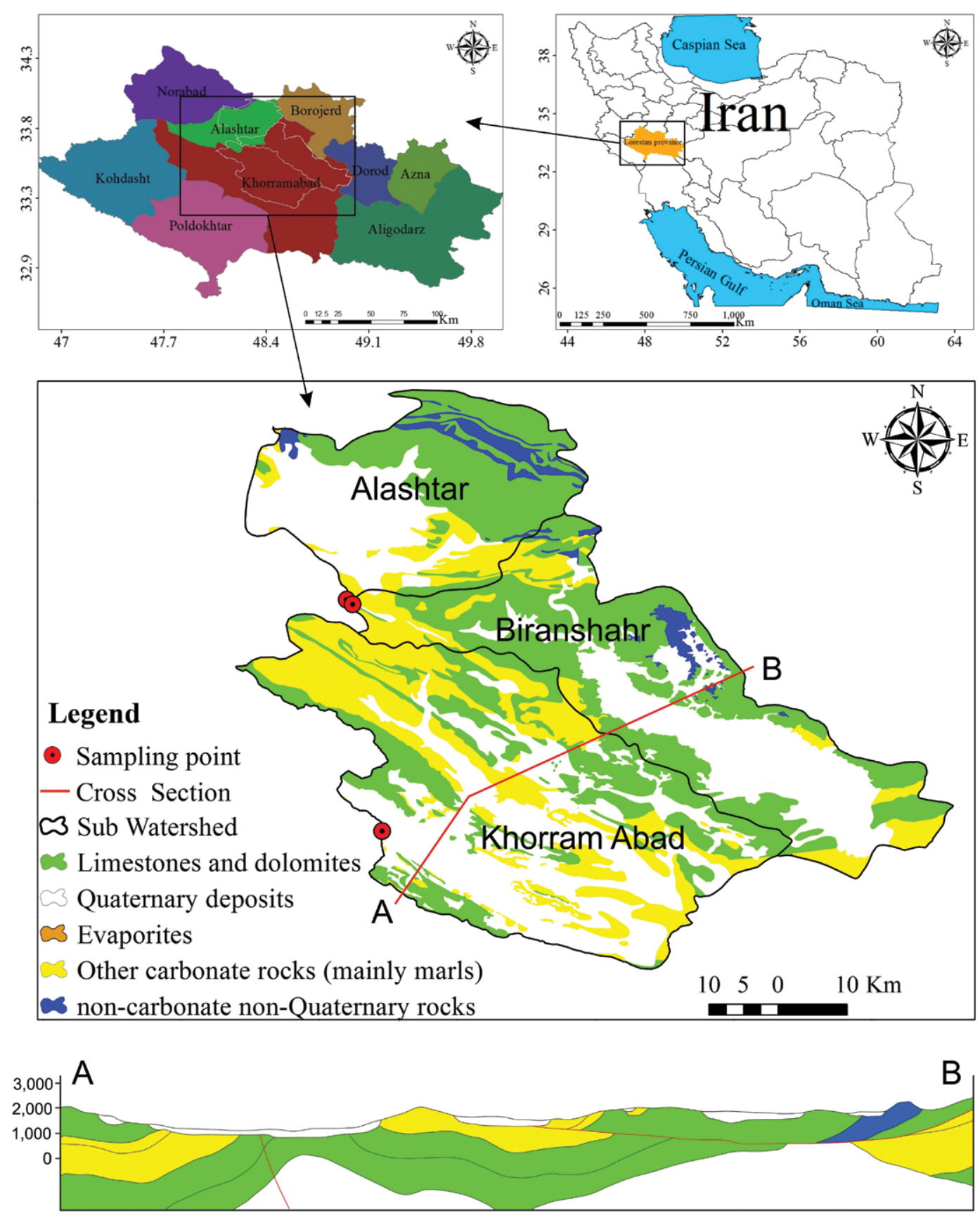

Figure 1. Map of the study area showing geological characteristics and location of sampling sites. is characteristic of the Mediterranean climate. Also, due to high altitude and continental influences, snow cover lasts 109, 49 and 56 days per year in Alashtar, Khorram Abad, and Biranshahr, respectively. During the measurement period, the river regimes, with primary spring and secondary autumn peaks, corresponded to 30-years-long average (1986-2016). However, due to the relatively low discharge in spring months, average annual discharge during the measurement period was lower by $27 \%, 37 \%$, and $36 \%$ compared to the 30-year-long average at Alashtar, Khorram Abad, and Biranshahr, respectively. While precipitation was on average $14 \%$ higher than the 30-year-long average and all mean discharges of the bigger springs in the watersheds (Honam, Motaheri, Golestan, and Bid Hal) were 36-66 \% lower than average, the main reason for the smaller discharges in the studied watersheds is thought to be higher evapotranspiration.

\section{METHODS AND MATERIALS}

Stream water was collected for one year from September 2014 to September 2015 (Appendix 1-3). Water samples were collected at depths of 30-100 cm approximately in the middle of the channel. The samples were collected in prewashed $1 \mathrm{~L}$ polyethylene bottles three times a month. Electrical conductivity $(\mathrm{EC})$, temperature and pH were measured using a portable multipara function (Lutron WA-2017SD) precalibrated before fieldwork with standard 4.01, 7.00, and 10.01 buffer solutions.

The samples were refrigerated and transported to the laboratory where chemical analyses were carried out within 1 day of collection. Chemical analysis of water samples $\left(\mathrm{Cl}^{-}, \mathrm{SO}_{4}{ }^{2-}, \mathrm{Ca}^{2+}, \mathrm{Mg}^{2+}, \mathrm{Na}^{+}\right.$, and $\left.\mathrm{K}^{+}\right)$was performed at the laboratory at the Natural Resources Faculty of Tehran University using a DIONEX ICS-2000 ion chromatograph, an AS18 (4 mm) analytical column and a CS16 $(5 \mathrm{~mm})$ analytical column. Alkalinity $\left(\mathrm{HCO}_{3}{ }^{+}\right.$and $\left.\mathrm{CO}_{3}{ }^{2-}\right)$ was determined by automatic titration using a digital titrator. The error of the analysis was calculated using the ion charge balance control 
Table 1. Basic lithological, hydrological, and hydrochemical characteristics of the subwatersheds. The extent (A) of carbonate outcrops of the individual catchment is further divided into limestones (L) with dolomites (D), marls (M), Quaternary deposits (Q), and evaporates (E).

\begin{tabular}{|c|c|c|c|}
\hline $\begin{array}{l}\text { Lithological, Hydrological, and } \\
\text { Hydrochemical Characteristics }\end{array}$ & Alashtar & Khorram Abad & Biranshahr \\
\hline \multicolumn{4}{|l|}{ Surface Land Area } \\
\hline Subwatershed area $\left(\mathrm{km}^{2}\right)$ & 804 & 1611 & 1160 \\
\hline$A_{L+D}\left(k^{2} \%\right)$ & $350.9(43.6 \%)$ & $402.3(25.0 \%)$ & $508.4(43.8 \%)$ \\
\hline$A_{L+D+M}\left(k m^{2} \%\right)$ & $446.4(55.5 \%)$ & $857.3(53.2 \%)$ & $667.1(57.5 \%)$ \\
\hline$A_{L+D+M+Q}\left(k m^{2} \%\right)$ & $737.6(91.7 \%)$ & $1601.8(99.4 \%)$ & $1127.5(97.2 \%)$ \\
\hline$A_{L+D+M+Q+E}\left(k^{2} \%\right)$ & $742.6(92.3 \%)$ & $1611.1(100.0 \%)$ & $1127.5(97.2 \%)$ \\
\hline non-carbonate $\left(\mathrm{km}^{2} \%\right)$ & $61.8(7.7 \%)$ & $0.0(0 \%)$ & $32.8(2.8 \%)$ \\
\hline \multicolumn{4}{|l|}{ Surface Hydrology } \\
\hline Precipitation during measurement period $\left(\mathrm{mm} \mathrm{a}^{-1}\right)$ & 491 & 539 & 754 \\
\hline Total runoff $\left(\mathrm{Mm}^{3} \mathrm{a}^{-1}\right)$ & 170.8 & 168.8 & 198.1 \\
\hline Specific discharge $\left(\mathrm{L} \mathrm{s}^{-1} \mathrm{~km}^{-2}\right)$ & 6.4 & 6.4 & 7.5 \\
\hline Average Discharge $\left(\mathrm{m}^{3} \mathrm{~s}^{-1}\right)$ & $5.42 \pm 2.73$ & $5.35 \pm 3.45$ & $6.28 \pm 4.87$ \\
\hline $\operatorname{TDS}_{\text {AVG }}\left(\mathrm{mg} \mathrm{L}^{-1}\right)$ & $277 \pm 69$ & $405 \pm 81$ & $266 \pm 52$ \\
\hline $\mathrm{EC}_{\mathrm{AVG}}\left(\boldsymbol{\mu} \mathbf{S} \mathrm{cm}^{-1}\right)$ & $431 \pm 110$ & $641 \pm 133$ & $414 \pm 81$ \\
\hline $\mathrm{pH}_{\mathrm{AVG}}^{\mathrm{a}}$ & 7.29 & 7.08 & 7.79 \\
\hline \multicolumn{4}{|l|}{ Surface Hydrochemistry } \\
\hline Alkalinity $\left(\mathrm{mmol} \mathrm{L}^{-1}\right)$ & $3.65 \pm 0.81$ & $4.66 \pm 0.95$ & $3.35 \pm 0.48$ \\
\hline $\mathrm{Cl}^{-}(\mathrm{mmol} \mathrm{L}-1)$ & $0.45 \pm 0.14$ & $1.43 \pm 0.36$ & $0.45 \pm 0.39$ \\
\hline $\mathrm{SO}_{4}{ }^{2-}\left(\mathrm{mmol} \mathrm{L}^{-1}\right)$ & $0.15 \pm 0.11$ & $0.21 \pm 0.24$ & $0.18 \pm 0.11$ \\
\hline $\mathrm{Ca}^{2+}\left(\mathrm{mmol} \mathrm{L}^{-1}\right)$ & $1.33 \pm 0.47$ & $1.77 \pm 0.40$ & $1.35 \pm 0.25$ \\
\hline $\mathrm{Mg}^{2+}\left(\mathrm{mmol} \mathrm{L}^{-1}\right)$ & $0.68 \pm 0.37$ & $1.14 \pm 0.44$ & $0.59 \pm 0.26$ \\
\hline $\mathrm{Na}^{+}\left(\mathrm{mmol} \mathrm{L}^{-1}\right)$ & $0.22 \pm 0.21$ & $0.56 \pm 0.45$ & $0.26 \pm 0.32$ \\
\hline $\mathrm{K}^{+}(\mathrm{mmol} \mathrm{L}-1)$ & $0.06 \pm 0.06$ & $0.15 \pm 0.18$ & $0.03 \pm 0.02$ \\
\hline
\end{tabular}

${ }^{a} \mathrm{pH}$ values were converted to hydrogen-ion concentrations before calculation of the means and standard deviations.

$(|[C]-[A] / /[C]+[A]|)$; an error of $>5 \%$ was found in 13 of 36 samples, in 1 of 36 samples, and none in the 36 samples at Alashtar, Khorram Abad, and Biranshahr subwatersheds, respectively. The average of an absolute value of the error indicates the quality of data as being the best in Biranshahr $(-0.3 ; 0.8)$ and the worst in Alashtar subwatershed $(-2.7$; 4.9). The predominantly negative charge balance error suggests that mainly cations were underestimated. Due to the acceptable average annual error, all data have been used in the calculation. Some caution should be adopted when results from the Alashtar subwatershed are considered where the reason for the high predominantly negative charge balance error is unknown: Pearson's correlation matrix in Table 2 suggests low impact of urban or agricultural pollutants like $\mathrm{Cl}^{-}$and $\mathrm{K}^{+}$and excess of $\mathrm{Ca}^{2+}$.

To analyze suspended load, the samples were collected in prewashed $1 \mathrm{~L}$ polyethylene bottles and analyzed at the same institution as the chemical analyses. The samples were unmoved for $48 \mathrm{~h}$ to allow the suspended sediment to settle and the upper sediment-free part of the water column decanted. The remaining suspension was filtered through pre-weighed Whatman filter papers (Chow et al., 2007), dried at $105^{\circ} \mathrm{C}$ in an oven for $24 \mathrm{~h}$ (Sadeghi et al., 2009; Sadeghi and Saeidi, 2010), weighed again, and the weight difference calculated.

The stream discharge was measured by combining velocity measurements, using a propeller-type current meter, corrected for 0.85 (to get representative average river flow velocity), and the wetted cross-section area to give the instantaneous discharge at the moment of sampling. Discharge measurements are consistent with the procedure of The Regional Water Company of Lorestan that performs regular discharge measurements at various sampling locations. The speciation, the degree of saturation with respect to calcite $\left(\mathrm{SI}_{\mathrm{Cal}}\right)$, and equilibrium $p \mathrm{CO}_{2}$ of the waters were calculated using the PHREEQC Interactive geochemical code, version 3.1.7.9213 (Parkhurst and Appello, 2013). 


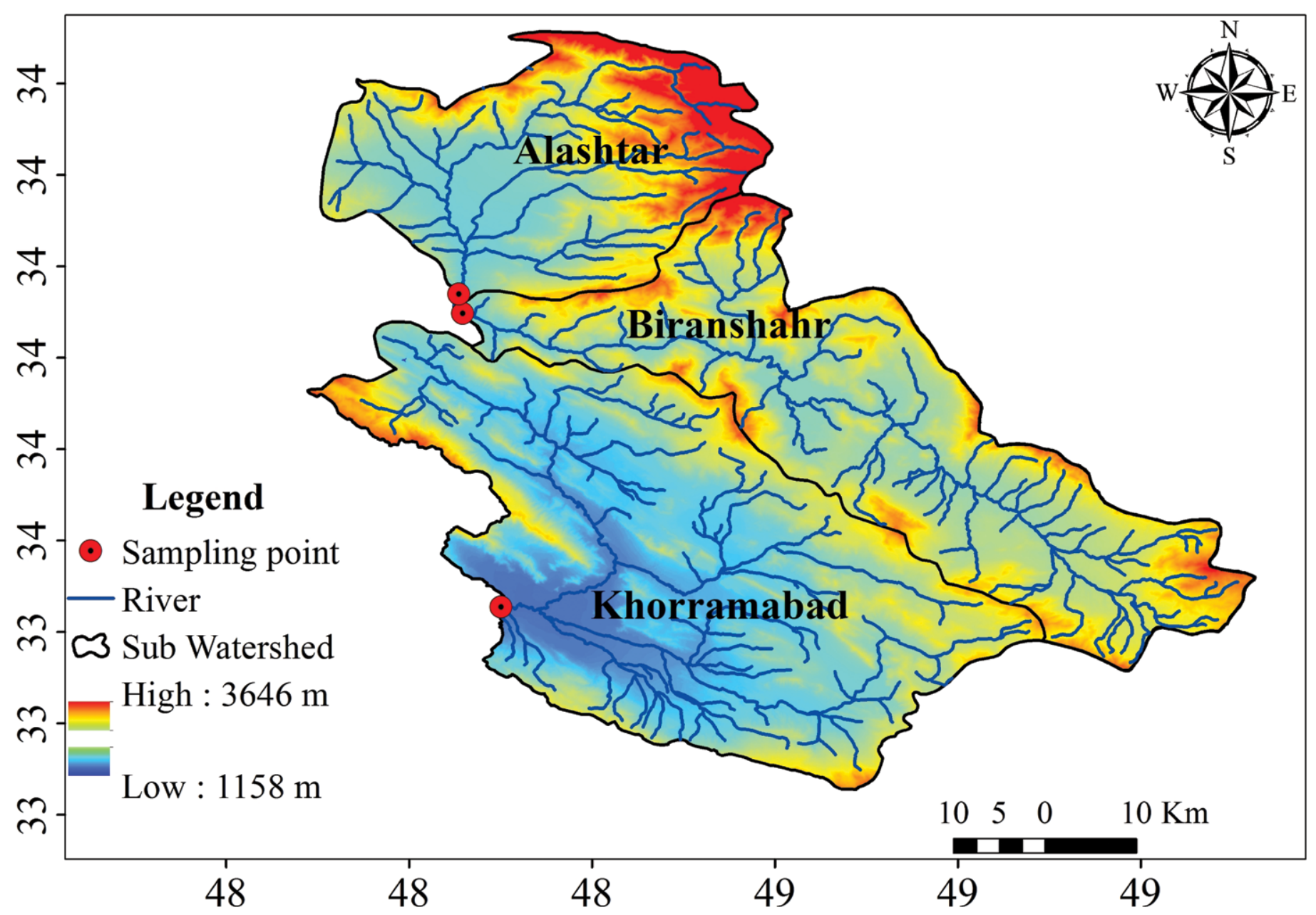

Figure 2. Terrain, hydrological network and subwatersheds of the study area.

\section{Calculation of the net solutional denudation rate of carbonates}

Three equations were used for calculation of the net solutional denudation rate of carbonates. An annual quantity of dissolved carbonates (limestone and dolomite) was calculated as a running total of all $\mathrm{Ca}^{2+}$ and $\mathrm{Mg}^{2+}$ fluxes at the sampling times by Equation (1)

$$
S_{c}=\sum_{i=1}^{36}\left[C_{i} Q_{i}\left(\frac{365}{36} \times 24 \times 60 \times 60\right)\right]
$$

where $S_{c}\left(\mathrm{~kg}\right.$ as $\left.\mathrm{CaCO}_{3} \mathrm{a}^{-1}\right)$ refers to the sum of $\mathrm{Ca}^{2+}$ and $\mathrm{Mg}^{2+}$ load per year expressed as calcite $\left(\mathrm{CaCO}_{3}\right), i$ refers to equal time intervals, $C_{i}\left(\mathrm{~kg}\right.$ as $\left.\mathrm{CaCO}_{3} \mathrm{~m}^{-3}\right)$ is the sum of the $\mathrm{Ca}^{2+}$ and $\mathrm{Mg}^{2+}$ concentration expressed as calcite during sampling campaigns, $Q_{i}\left(\mathrm{~m}^{3} \mathrm{~s}^{-1}\right)$ is discharge during sampling campaigns, and 36 refers to the annual number of samples. The last bracketed part of the equation was used for time conversion. Since the extent of evaporite outcrops in each subwatershed is not significantly reflected in measured $\mathrm{SO}_{4}{ }^{2-}$ concentration, $\mathrm{Ca}^{2+}$ concentration was not reduced for molar concentration of $\mathrm{SO}_{4}^{2-}$ that could, to some extent, derive from gypsiferous evaporates.

The volume of dissolved carbonates $\left(V_{c}\right.$ in $\left.\mathrm{m}^{3}\right)$ was obtained by Equation (2)

$$
V_{c}=\frac{s_{c}}{\rho_{c}}
$$

where $\rho_{c}$ is the weighted average of the specific gravities $\left(\mathrm{kg} \mathrm{m}^{-3}\right)$ which is $2,634 \mathrm{~kg} \mathrm{~m}^{-3}$ (average of 6 sampled limestones in all subwatersheds).

The carbonate karst denudation rate was calculated by Equation (3)

$$
D=\frac{v_{c}}{A} 10^{9}
$$

where $D$ is the solutional denudation rate of carbonates $\left(\mathrm{mm} \mathrm{a}^{-1}\right)$ and $A\left(\mathrm{~km}^{2}\right)$ is the area of carbonate outcrop. Since the latter is not related to limestone and dolomite outcrops only, carbonate dissolution rate was separately calculated 
for area of limestones and dolomites only $\left(A_{L+D}\right)$, extended for outcrops containing substantial amounts of carbonates (mainly marls; $A_{L+D+M}$ ), extended for Quaternary carbonate-bearing deposits $\left(A_{L+D+M+Q}\right)$, and extended for evaporites $\left(A_{L+D+M+Q+E}\right)$, the differences between which are marked, especially due to the vast extent of Quaternary deposits in all subwatersheds and marls in Khorram Abad (Table 1). The subdivision of the studied subwatersheds into homogeneous sub-basins to avoid the impact of allogenic streams on solutional denudation rates of carbonate karst, proposed by Lauritzen (1990), was not possible due to the spatial complexity of the subwatersheds. Therefore, the results can be considered as an outcome of a mixed denudation system (Ford and Williams, 2007).

\section{RESULTS}

In all three subwatersheds, the increasing order of the average solute molar concentrations (Table 1), as well as the solute molar flux, is $\mathrm{Ca}^{2+}>\mathrm{Mg}^{21+}>\mathrm{Na}^{+}-\mathrm{K}^{+}$for cations and $\left(\mathrm{HCO}_{3}{ }^{-}+\mathrm{CO}_{3}{ }^{2-}\right)>>\mathrm{Cl}^{-}>\mathrm{SO}_{4}{ }^{2-}$ for anions. On average, the sum of bicarbonate and carbonate ions represents from 74 to $84 \mathrm{~mol} \%$ of all analyzed anions. Among major cations, $\mathrm{Ca}^{2+}(51-62 \mathrm{~mol} \%)$ is most closely followed by $\mathrm{Mg}^{2+}(27-33 \mathrm{~mol} \%)$.

Ternary plots (Fig. 3) indicate the prevalence of $\mathrm{Ca}-\mathrm{Mg}-\mathrm{HCO}_{3}$ water for all three subwatersheds. Khorram Abad is notably characterized by a relatively higher share of $\mathrm{Cl}^{-}$as well as $\mathrm{Na}^{+}$indicating dissolution of $\mathrm{Na}^{+}$and $\mathrm{Cl}^{-}$bearing rocks (e.g. halite). A sample from Biranshahr taken in the middle of May 2015 has an exceptionally high concentration of $\mathrm{Cl}^{-}$and $\mathrm{Na}^{+}$and is most probably an outlier related to contamination with salt in the field or laboratory as the concentration is far higher than expected from the discharge (Fig. 4A) or runoff (Fig. 4B), and small charge-balance error
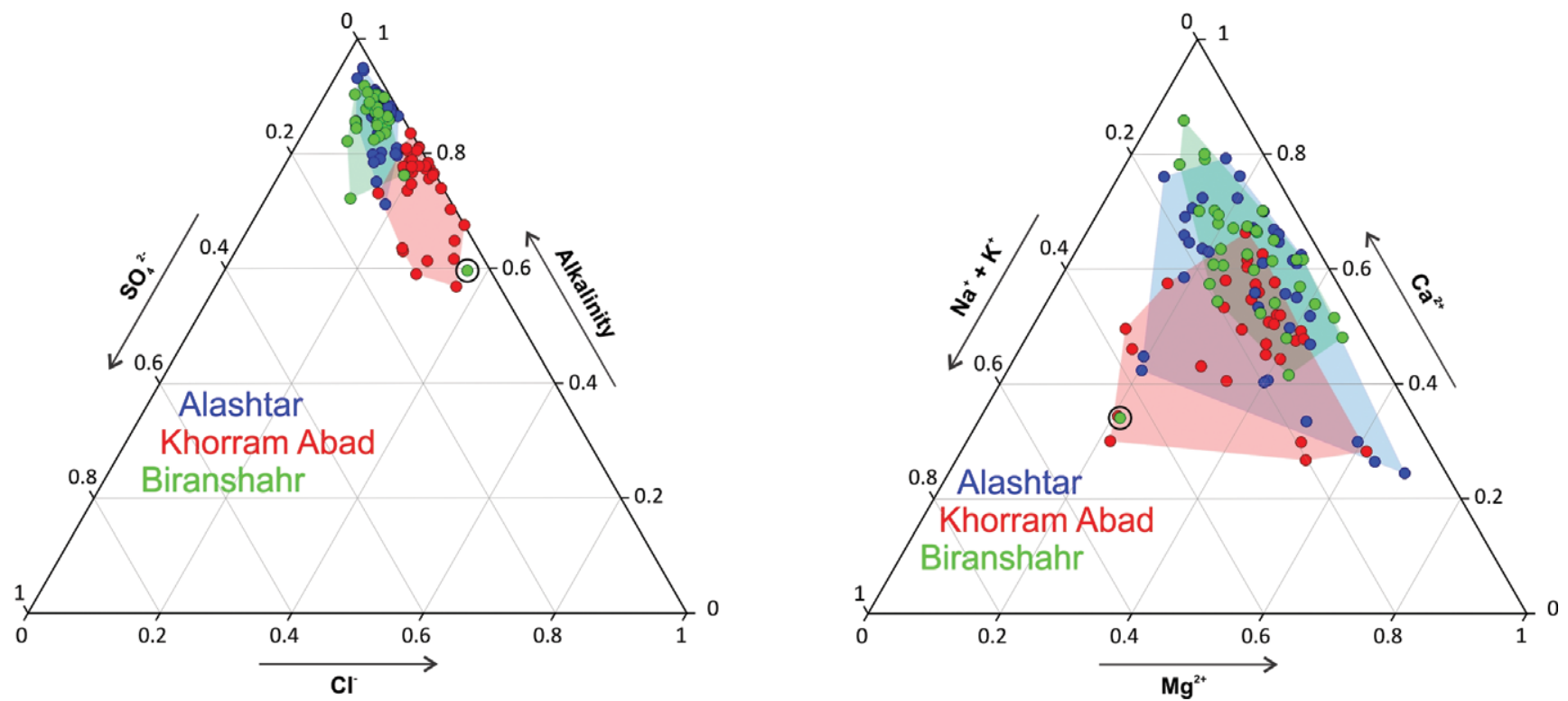

Figure 3. Ternary plot of the major anions and cations (in mol\%) for the three studied subwatersheds. The encircled sample is recognized to be an outlier and was excluded from further evaluation.
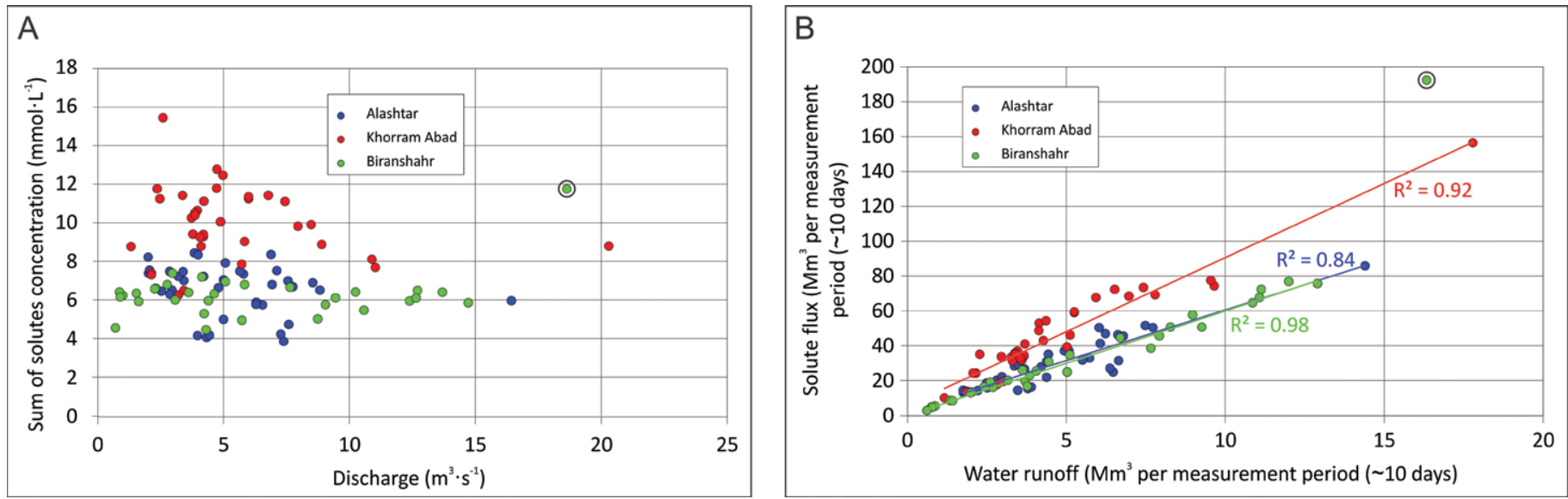

Figure 4. Relations between (A) solute concentration and discharge and (B) solute runoff and water runoff. An outstanding value (outlier) detected in Biranshahr subwatershed is circled and was excluded from calculation of the $r^{2}$. 
$(+0.1)$, while the concentrations of other ions are within expectations. The dominant concentrations of $\mathrm{Ca}^{2+}$ and $\mathrm{Mg}^{2+}$ among other cations (usually $>80 \mathrm{~mol} \%$ ) and (bi)carbonate (usually $>70 \mathrm{~mol} \%$ ) indicates dissolution of limestone as well as dolomite. The share of $\mathrm{SO}_{4}{ }^{2-}$ is low in all three subwatersheds (usually $>10 \mathrm{~mol} \%$ ) indicating a relatively small amount of dissolution of gypsum compared to limestones and dolomites.

All solute concentrations (Table 1), as well as annual solute flux, are highest in Khorram Abad subwatershed. The other two are similar in solute concentrations but Biranshahr shows a higher solute flux due to higher total runoff. If subwatershed areas are taken into account, solute flux per area is the highest in Alashtar $\left(1.356 \mathrm{Mmol} \mathrm{km}^{-2} \mathrm{a}^{-1} \mathrm{or}^{-1}\right.$ $\left.68.55 \mathrm{t} \mathrm{km}^{-2} \mathrm{a}^{-1}\right)$ followed by Biranshahr $\left(1.049 \mathrm{Mmol} \mathrm{km}^{-2} \mathrm{a}^{-1}\right.$ or $\left.53.61 \mathrm{t} \mathrm{km}^{-2} \mathrm{a}^{-1}\right)$ and Khorram Abad $\left(1.02 \mathrm{Mmol} \mathrm{km}^{-2} \mathrm{a}^{-1}\right.$ or $\left.48.54 \mathrm{t} \mathrm{km}^{-2} \mathrm{a}^{-1}\right)$.

The connection between discharge and the sums of solutes is weak and not statistically significant in all three studied cases (Table 2, Fig. 4A). The lowest sums of solute concentrations were not recorded during flood events showing

Table 2. Pearson's correlation matrix between measured parameters and dissolved species for all three studied subwatersheds (top: Alashtar; middle: Khorram Abad; bottom: Biranshahr; $\Sigma$ sol = sum of solutes; C-B_e = charge-balance error).

\begin{tabular}{|c|c|c|c|c|c|c|c|c|c|c|c|c|c|c|c|}
\hline & $p \mathrm{CO}_{2}$ & $\mathrm{SI}_{\mathrm{Cal}}$ & C-B_e & $\Sigma_{\text {sol }}$ & $\mathbf{K}^{+}$ & $\mathrm{Na}^{+}$ & $\mathbf{M g}^{2+}$ & $\mathrm{Ca}^{2+}$ & $\mathrm{SO}_{4}{ }^{2-}$ & $\mathrm{Cl}^{-}$ & $\mathrm{HCO}_{3}^{-}$ & $\mathrm{CO}_{3}{ }^{2-}$ & $\mathrm{pH}$ & EC & TDS \\
\hline \multirow[t]{3}{*}{ Q } & -0.08 & 0.02 & -0.13 & -0.24 & -0.24 & -0.01 & -0.25 & -0.03 & 0.19 & 0.14 & -0.28 & -0.02 & 0.07 & -0.26 & -0.28 \\
\hline & 0.02 & -0.06 & -0.35 & -0.15 & -0.18 & -0.03 & -0.12 & -0.09 & -0.09 & 0.04 & -0.15 & 0.07 & -0.04 & -0.13 & -0.06 \\
\hline & 0.03 & 0.05 & 0.07 & 0.09 & 0.33 & -0.22 & 0.17 & 0.06 & 0.04 & 0.05 & 0.14 & -0.13 & 0.03 & 0.30 & 0.30 \\
\hline \multirow[t]{3}{*}{ TDS } & 0.02 & 0.15 & 0.22 & 0.87 & 0.52 & -0.04 & 0.58 & 0.37 & 0.25 & 0.47 & 0.79 & -0.01 & -0.09 & 0.96 & \\
\hline & 0.35 & 0.01 & 0.14 & 0.75 & -0.08 & 0.20 & 0.51 & 0.61 & 0.49 & 0.52 & 0.60 & -0.06 & -0.19 & 0.82 & \\
\hline & -0.02 & 0.32 & 0.06 & 0.79 & 0.52 & -0.09 & 0.53 & 0.46 & 0.38 & 0.35 & 0.73 & -0.02 & 0.13 & 1.00 & \\
\hline \multirow[t]{3}{*}{ EC } & 0.02 & 0.16 & 0.14 & 0.89 & 0.52 & -0.03 & 0.60 & 0.33 & 0.25 & 0.47 & 0.82 & 0.00 & -0.07 & & \\
\hline & 0.23 & 0.24 & 0.13 & 0.98 & 0.49 & 0.44 & 0.49 & 0.67 & 0.58 & 0.61 & 0.76 & 0.09 & 0.03 & & \\
\hline & -0.02 & 0.32 & 0.04 & 0.81 & 0.52 & -0.11 & 0.54 & 0.46 & 0.38 & 0.32 & 0.75 & 0.00 & 0.13 & & \\
\hline \multirow[t]{3}{*}{$\mathrm{pH}$} & -0.87 & 0.90 & 0.04 & -0.09 & -0.13 & 0.28 & -0.21 & 0.05 & 0.31 & 0.02 & -0.19 & 0.03 & & & \\
\hline & -0.88 & 0.95 & -0.17 & 0.05 & 0.26 & 0.24 & -0.09 & -0.09 & 0.01 & -0.05 & 0.03 & 0.20 & & & \\
\hline & -0.93 & 0.94 & 0.04 & -0.02 & -0.08 & 0.31 & -0.31 & 0.22 & -0.32 & 0.21 & -0.02 & 0.21 & & & \\
\hline \multirow{3}{*}{$\mathrm{CO}_{3}{ }^{2-}$} & -0.07 & 0.01 & -0.14 & 0.08 & -0.20 & 0.73 & -0.14 & -0.02 & 0.42 & 0.33 & -0.14 & & & & \\
\hline & -0.04 & 0.21 & -0.48 & 0.13 & 0.18 & 0.32 & -0.13 & 0.04 & 0.08 & 0.10 & 0.01 & & & & \\
\hline & -0.12 & 0.24 & -0.52 & 0.15 & 0.02 & -0.05 & 0.04 & 0.06 & -0.22 & -0.30 & 0.21 & & & & \\
\hline \multirow{3}{*}{$\mathrm{HCO}_{3}{ }^{-}$} & 0.15 & 0.16 & -0.02 & 0.92 & 0.41 & -0.12 & 0.28 & 0.57 & -0.05 & 0.26 & & & & & \\
\hline & 0.18 & 0.28 & 0.20 & 0.83 & 0.41 & -0.02 & 0.57 & 0.59 & 0.01 & 0.13 & & & & & \\
\hline & 0.17 & 0.27 & -0.18 & 0.93 & 0.39 & 0.01 & 0.38 & 0.58 & 0.03 & 0.00 & & & & & \\
\hline \multirow[t]{3}{*}{$\mathrm{Cl}^{-}$} & 0.08 & 0.13 & -0.05 & 0.50 & 0.12 & 0.35 & 0.20 & 0.20 & 0.49 & & & & & & \\
\hline & 0.17 & 0.01 & 0.15 & 0.57 & 0.35 & 0.33 & 0.22 & 0.41 & 0.45 & & & & & & \\
\hline & 0.08 & 0.15 & 0.00 & 0.26 & -0.18 & 0.09 & 0.02 & 0.09 & 0.10 & & & & & & \\
\hline \multirow{3}{*}{$\mathrm{SO}_{4}{ }^{2-}$} & -0.21 & 0.32 & -0.01 & 0.24 & 0.03 & 0.34 & 0.10 & 0.10 & & & & & & & \\
\hline & 0.12 & 0.03 & -0.09 & 0.48 & 0.19 & 0.62 & 0.15 & 0.27 & & & & & & & \\
\hline & 0.25 & -0.28 & 0.19 & 0.28 & 0.19 & -0.42 & 0.45 & 0.10 & & & & & & & \\
\hline \multirow[t]{3}{*}{$\mathrm{Ca}^{2+}$} & -0.04 & 0.46 & 0.39 & 0.64 & 0.13 & 0.07 & -0.40 & & & & & & & & \\
\hline & 0.27 & 0.20 & 0.01 & 0.66 & 0.23 & 0.14 & -0.06 & & & & & & & & \\
\hline & -0.02 & 0.52 & 0.08 & 0.59 & 0.23 & -0.03 & -0.36 & & & & & & & & \\
\hline \multirow[t]{3}{*}{$\mathrm{Mg}^{2+}$} & 0.13 & -0.29 & 0.13 & 0.30 & 0.35 & -0.33 & & & & & & & & & \\
\hline & 0.12 & -0.04 & 0.39 & 0.52 & 0.13 & -0.25 & & & & & & & & & \\
\hline & 0.24 & -0.31 & -0.09 & 0.47 & 0.31 & -0.32 & & & & & & & & & \\
\hline \multirow[t]{3}{*}{$\mathrm{Na}^{+}$} & -0.28 & 0.27 & -0.08 & 0.10 & -0.19 & & & & & & & & & & \\
\hline & 0.02 & 0.23 & -0.14 & 0.38 & 0.36 & & & & & & & & & & \\
\hline & -0.22 & 0.09 & 0.02 & -0.03 & -0.42 & & & & & & & & & & \\
\hline \multirow[t]{3}{*}{$\mathrm{K}^{+}$} & 0.10 & -0.03 & 0.14 & 0.43 & & & & & & & & & & & \\
\hline & -0.08 & 0.32 & 0.12 & 0.56 & & & & & & & & & & & \\
\hline & 0.19 & 0.03 & 0.23 & 0.33 & & & & & & & & & & & \\
\hline \multirow{3}{*}{$\Sigma_{\text {sol }}$} & 0.06 & 0.26 & 0.15 & & & & & & & & & & & & \\
\hline & 0.22 & 0.27 & 0.18 & & & & & & & & & & & & \\
\hline & 0.15 & 0.26 & 0.06 & & & & & & & & & & & & \\
\hline \multirow[t]{3}{*}{ C-B_e } & -0.13 & 0.16 & & & & & & & & & & & & & \\
\hline & 0.15 & -0.16 & & & & & & & & & & & & & \\
\hline & 0.00 & 0.02 & & & & & & & & & & & & & \\
\hline \multirow[t]{3}{*}{$\mathrm{SI}_{\mathrm{Cal}}$} & -0.79 & & & & & & & & & & & & & & \\
\hline & -0.78 & & & & & & & & & & & & & & \\
\hline & -0.80 & & & & & & & & & & & & & & \\
\hline
\end{tabular}


a minor effect of dilution during high discharge. As a result, in the available data, seasonal fluctuations of solute runoff mostly depend on seasonally (or event-driven) discharge indicated also by very high $r^{2}$ values (Fig. 4B). In all three cases, the solute runoff seasonal maxima are observed in spring months and minima in autumn reflecting the river flow regimes (Fig. 5). The impact of single flood events on solute runoff is very high with more than a two-fold increase of solute runoff above usual as can be observed in February 2015 in Khorram Abad and in May 2015 in the Biranshahr subwatershed. Even on the scale of individual parameters (Table 2), Pearson correlation coefficients between discharge and anions or cations are usually negative to very low with high variation between subwatersheds.

Pearson's correlation matrix (Table 2) shows expectedly high positive and significant correlations between TDS (or $\mathrm{EC}$ ) and the sums of solutes, as well as with all major ions $\left(\mathrm{HCO}_{3}^{-}, \mathrm{Mg}^{2+}, \mathrm{Ca}^{2+}\right.$ as well as $\mathrm{Cl}^{-}, \mathrm{K}^{+}$, and $\mathrm{SO}_{4}{ }^{2-}$ but to a lesser extent). Besides $\mathrm{Mg}^{2+}-\mathrm{Ca}^{2+}$ and $\mathrm{Mg}^{2+}-\mathrm{Na}^{+}$pairs, generally positive correlation can be found between major ionic species. Relatively high and significant positive correlation is evident for $\mathrm{HCO}_{3}^{-}$with $\mathrm{Ca}^{2+}, \mathrm{K}^{+}$and $\mathrm{Mg}^{2+}$. Except in the Biranshahr subwatershed, $\mathrm{Cl}^{-}$is positively correlated with $\mathrm{SO}_{4}{ }^{2-}$ and $\mathrm{Na}^{+}$. Significant correlation of TDS or EC with $\mathrm{Na}^{+}$is mostly absent indicating different mechanisms of $\mathrm{Na}^{+}$transport compared to other major ions. Additionally, correlation between $\mathrm{Ca}^{2+}$ and $\mathrm{SO}_{4}{ }^{2-}$ as well as $\mathrm{Na}^{+}$and $\mathrm{Cl}^{-}$, which could indicate dissolution of gypsum $\left(\mathrm{CaSO}_{4} \cdot 2 \mathrm{H}_{2} \mathrm{O}\right)$ and halite $(\mathrm{NaCl})$, respectively, is weak and it is significant for $\mathrm{Na}^{+}-\mathrm{Cl}^{-}$ionic pair only in the case of the Alashtar and Khorram Abad subwatersheds. The seasonal course of the $\mathrm{Na}^{+} / \mathrm{Cl}^{-}$ratio shows extremely high annual variation being 0.06-1.48, 0.12-1.10, and 0.10-2.26 for the Alashtar, Khorram Abad, and Biranshahr subwatersheds, respectively. In the Alashtar and Khorram Abad, oscillation during measurement period occurs in the form of waves with 3-4 peaks. Much better Pearson's correlations exist between groups of common ion-pairs (e.g. between $\left(\mathrm{Ca}^{2+}+\mathrm{Mg}^{2+}\right)$ and $\left(\mathrm{HCO}_{3}{ }^{-}+\mathrm{CO}_{3}{ }^{2-}\right)$ being $+0.79,+0.84$ and +0.83 for Alashtar, Khorram Abad, and Biranshahr, respectively. As expected, the highest significant correlations (TDS-EC, $\mathrm{pH}-\mathrm{SI}_{\mathrm{Cal}}, \mathrm{pH}-p \mathrm{CO}_{2}, \mathrm{SI}_{\mathrm{Cal}}-p \mathrm{CO}_{2}$ ) are characteristic for dependent parameters in karst waters.

Based on the geological map (Fig. 1), the concentration of $\mathrm{Ca}^{2+}$ can be mainly attributed to limestone and gypsum dissolution while $\mathrm{Mg}^{2+}$ can be mainly attributed to dissolution of dolomite. In the case of solely and moderate to intensive limestone or dolomite dissolution, if concentrations of less abundant species, such as, $\mathrm{H}^{+}$and $\mathrm{OH}^{-}$are neglected, $\left(\mathrm{Ca}^{2+}+\mathrm{Mg}^{2+}\right) /\left(\mathrm{HCO}_{3}^{+}+\mathrm{CO}_{3}^{2-}\right)$ molar ratios should be close to 0.5 ; in all researched subwatersheds it is higher $(0.55-0.63)$ indicating $\mathrm{CO}_{2}$ outgassing and/or additional sources of $\mathrm{Ca}^{2+}$, such as gypsum. The addition of $\mathrm{SO}_{4}{ }^{2-}$ to $\left(\mathrm{HCO}_{3}{ }^{-}+\mathrm{CO}_{3}{ }^{2-}\right)$ slightly reduces the molar ratio (0.53-0.61) and to some extent, explains the additional source of $\mathrm{Ca}^{2+}$ by dissolution

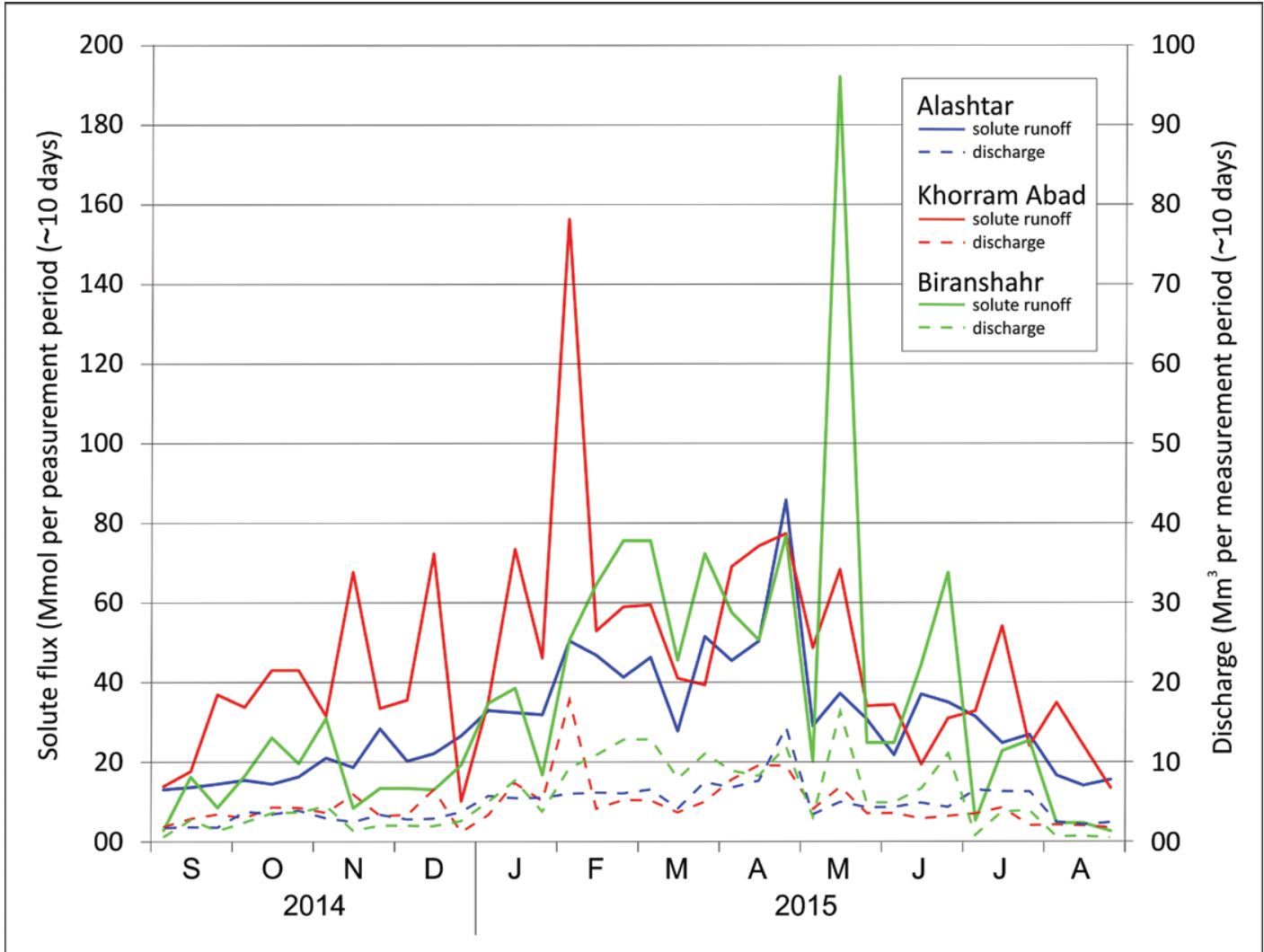

Figure 5. The seasonal course of solute runoff (full line) compared to discharge (dashed line). of gypsum. Based on the annual solute flux, the molar $\mathrm{SO}_{4}{ }^{2-} / \mathrm{Ca}^{2+}$ ratios are $0.12,0.11$, and 0.13 for Alashtar, Khorram Abad, and $\mathrm{Bi}-$ ranshahr, respectively, indicating the dominant (87-89 \%) effect of carbonate dissolution, while dissolution of gypsum $\left(\mathrm{CaSO}_{4} \cdot 2 \mathrm{H}_{2} \mathrm{O}\right)$ plays a minor role (11-13\%). Presence of $\mathrm{SO}_{4}{ }^{2-}$ and slightly positive Pearson's correlation between $\mathrm{Ca}^{2+}$ and $\mathrm{SO}_{4}{ }^{2-}$, which is not significant (Table 2) could indicate dissolution of gypsum. Therefore, to calculate the carbonate karst solutional denudation rate, the annual flux of $\mathrm{Ca}^{2+}$ and $\mathrm{Mg}^{2+}$ (as $\mathrm{CaCO}_{3}$ ) was related only to the area of carbonate-bearing depos- 
its (Table 1). Results show that the carbonate karst solutional denudation rate is between 0.011 and $0.045 \mathrm{~mm} \mathrm{a}^{-1}$ (or between 0.010 and $0.040 \mathrm{~mm} \mathrm{a}^{-1}$ if dissolution of gypsum is taken into account) (Table 3). Large variations are mostly a result of differences in the uncertain areas of carbonate-bearing deposits (2.1 times difference in Alashtar to up to 4 times difference in Khorram Abad) and, to a lesser extent, the differences between studied watersheds (1.3-1.5 times difference) indicating closer similarity of dissolution rates when based on the same rock type. Generally, the highest carbonate solutional denudation rates are at Alashtar and the lowest in the Biranshahr subwatershed.

The seasonal course of carbonate karst solutional denudation rate basically reflects seasonal fluctuations of discharge that is highest in late winter and during spring and is lowest during the late summer months and autumn in all subwatersheds (Fig. 6). The values of $r^{2}$ for linear Pearson's correlations of carbonate solutional denudation rate with discharge are high in

Table 3. Fluxes of $\mathrm{Ca}^{2+}$ and $\mathrm{Mg}^{2+}$ and solutional denudation rate from carbonate outcrops taking into account the areas of different carbonate-bearing deposits (L: limestones; D: dolomites; M: marls; Q: Quaternary deposits (see Table 1)) and the impact of gypsum dissolution (12\%, $11 \%$ and $13 \%$ for Alashtar, Khorram Abad and Biranshahr, respectively).

\begin{tabular}{|c|c|c|c|}
\hline Fluxes and Denudation Rates & Alashtar & Khorram Abad & Biranshahr \\
\hline \multicolumn{4}{|l|}{ Flux of $\mathrm{Ca}^{2+}+\mathrm{Mg}^{2+}$} \\
\hline $\mathrm{Mmol} \mathrm{a}^{-1}$ & 333.3 & 480.6 & 393.1 \\
\hline $\mathrm{t}$ as $\mathrm{CaCO}_{3} \mathrm{a}^{-1}$ & 33,359 & 48,104 & 39,347 \\
\hline $\mathrm{m}^{3}$ as $\mathrm{CaCO}_{3} \mathrm{a}^{-1}$ & 12,665 & 18,263 & 14,938 \\
\hline \multicolumn{4}{|c|}{ Solutional denudation rate $\left(\mathrm{mm}\right.$ as $\left.\mathrm{CaCO}_{3} \mathrm{a}^{-1}\right)$} \\
\hline$A_{L+D}$ & 0.032 & 0.040 & 0.025 \\
\hline$A_{L+D+M}$ & 0.025 & 0.019 & 0.019 \\
\hline$A_{L+D+M+0}$ & 0.015 & 0.010 & 0.011 \\
\hline
\end{tabular}

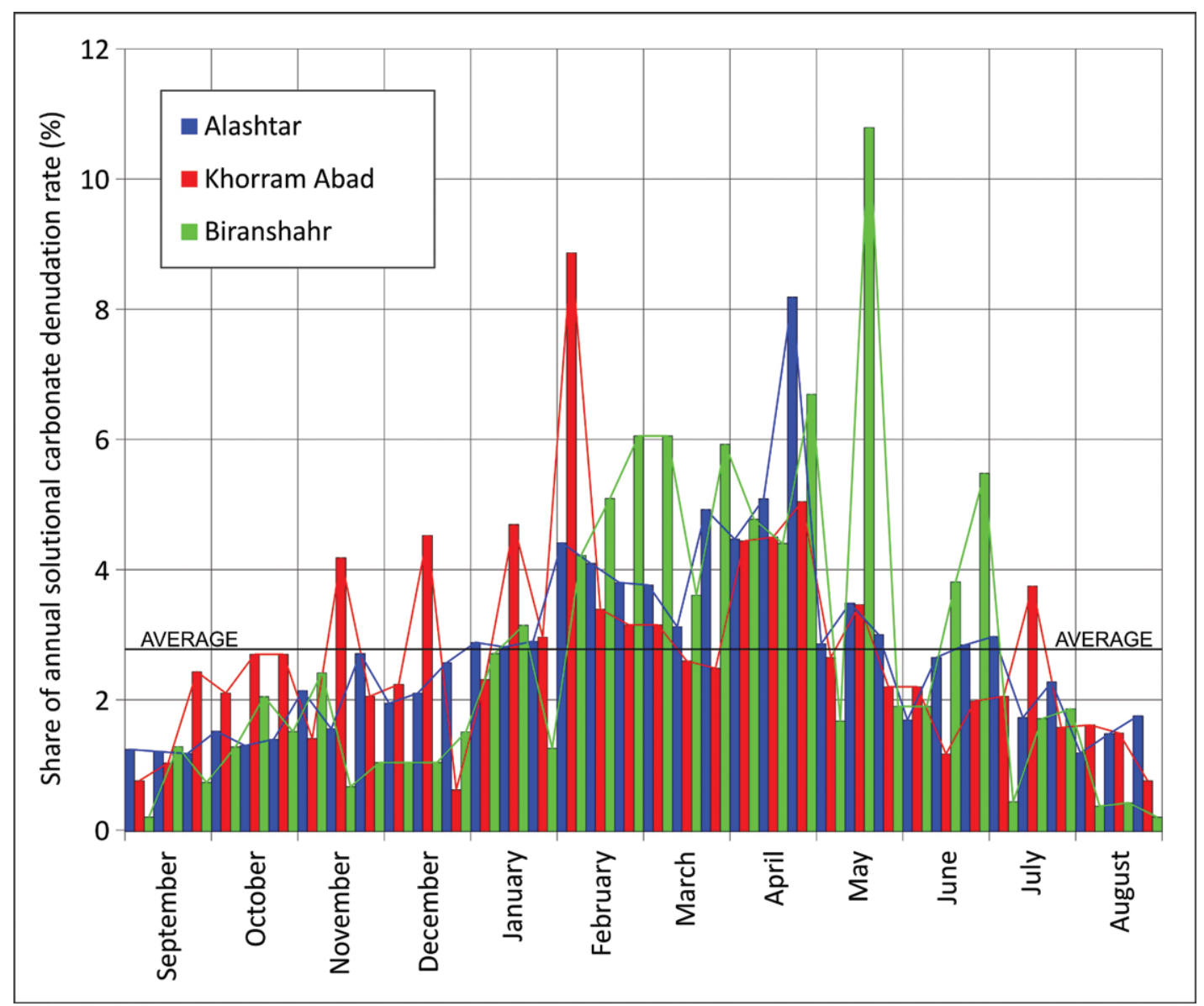

Figure 6. The annual course of solutional denudation rates. all three subwatersheds (i.e. 0.80, 0.91, and 0.95 for Alashtar, Khorram Abad, and Biranshahr, respectively). Especially during summer, fluctuations of solutional carbonate karst denudation rates depend strongly on floods; one event can be responsible for 8-11 \% of the annual solutional carbonate karst denudation rate (over 3-times the average). During low discharge, solutional carbonate karst denudation rates can be 10-times lower than for the average of all discharges. The highest annual fluctuations, as observed from standard the deviations, are $2.37 \%$ for the Biranshahr subwatershed and only $1.44 \%$ for Alashtar and $1.58 \%$ for Khorram Abad. 


\section{DISCUSSION}

Solute load and geological structure

The dominant $\mathrm{Ca}-\mathrm{Mg}-\mathrm{HCO}_{3}$ type of water is consistent with the geology (Fig. 1), with the previous hydrochemical studies in Zagros region (Barmaki et al., 2019) and indicates substantial dissolution of carbonate outcrops (Table 1). Concentrations of $\mathrm{Mg}^{2+}$ suggest a considerable extent of dolomite-bearing rocks (up to $51 \%, 64 \%$, and $44 \%$ of all carbonates in the case of Alashtar, Khorram Abad, and Biranshahr, respectively, if all $\mathrm{Mg}^{2+}$ derives from dolomite dissolution), as well as possibly other Mg-bearing rocks since Pearson's correlation coefficient, $r$, between $\mathrm{Mg}^{2+}$ and $\mathrm{HCO}_{3}{ }^{-}$is low for all subwatersheds and not significant for the Alashtar subwatershed (Table 2). The presence of $\mathrm{SO}_{4}{ }^{2-}, \mathrm{Cl}^{-}$, and $\mathrm{Na}^{+}$indicates the importance of evaporite rocks, especially in the Khorram Abad subwatershed. Higher concentration of $\mathrm{Cl}^{-}$and $\mathrm{Na}^{+}$(Fig. 3) in the case of Khorram Abad is expected due to $9.3 \mathrm{~km}^{2}$ ( $0.6 \%$ of subwatershed) of halite outcrops. Despite the share of halite outcrops in the Alashtar subwatershed being nearly the same $\left(0.6 \% ; 5 \mathrm{~km}^{2}\right)$, the concentrations of $\mathrm{Cl}^{-}$and $\mathrm{Na}^{+}$are low, which could be explained to some extent by slightly higher specific discharge in Alashtar resulting in higher dilution. However, the annual solute flux, which indicates the quantity of $\mathrm{Na}^{+}$or $\mathrm{Cl}^{-}$leaving a subwatershed in one year, does not support this. Since Biranshahr subwatershed shows very similar averages of $\mathrm{Cl}^{-}$and $\mathrm{Na}^{+}$concentration as Alashtar but higher annual solute flux than Alashtar (due to higher specific discharge and catchment area) despite an absence of mapped halite outcrops, halite deposits are probably more widespread than shown on the geological map of Biranshahr and Alashtar subwatersheds or halite is widely available as aeolian dust within the weathering zone. Average $\mathrm{SO}_{4}{ }^{2-} / \mathrm{Cl}^{-}$molar ratios $(0.36,0.14$, and 0.5 for Alashtar, Khorram Abad, and Biranshahr, respectively) suggest more intensive dissolution of halite than gypsum. Despite the fact that at least dissolution of carbonates could depend on seasonal $\mathrm{CO}_{2}$ production (Ford and Williams, 2007), none of the analyzed ions (except $\mathrm{Na}^{+}$to some extent) indicates strong seasonality.

The presence of $\mathrm{SO}_{4}{ }^{2-}$ could indicate dissolution of gypsum and/or the presence of natural or anthropogenic sources of $\mathrm{H}_{2} \mathrm{SO}_{4}$. While not significant but slightly positive Pearson's correlation between $\mathrm{Ca}^{2+}$ and $\mathrm{SO}_{4}{ }^{2-}$ (Table 2) could point to dissolution of gypsum, moderate to strong but always significant correlation between $\left(\mathrm{Ca}^{2+}+\mathrm{Mg}^{2+}\right) /\left(\mathrm{HCO}_{3}{ }^{-}+\mathrm{CO}_{3}{ }^{2-}\right)$ and $\mathrm{SO}_{4}{ }^{2-}(r=0.358$ and $\mathrm{p}<0.05, r=0.481$ and $p<0.05, r=0.84$ and $p<0.05$ for Alashtar, Khorram Abad, and Biranshahr, respectively) rather indicates the presence of $\mathrm{H}_{2} \mathrm{SO}_{4}$ as the source of $\mathrm{SO}_{4}{ }^{2-}$.

\section{IMPACT ON SOLUTE LOAD OF PRECIPITATION, BIOCHEMICAL ALTERATION AND INTERACTION WITH THE ATMOSPHERE}

Measured solute load is a result of precipitation input, biochemical dissolution, biochemical alteration (solute uptake/precipitation and release, ion-exchange processes) in weathering zones and water bodies, interaction with the atmosphere especially in surface flows (e.g., $\mathrm{CO}_{2}$ outgassing), and anthropogenic impacts such as contamination of air and water (from agriculture, industrial activity and domestic wastewater). To estimate the contribution of precipitation to solute load, the chemical composition of precipitation from the cities of Arak (Markazi Province, Iran; Ghadimi et al., 2013) and Shiraz (Fars province, Iran; Moore and Attar, 2011) was taken into account. Ion concentrations in rainwater summarized in Table 4 show high variability and very high averages, in the case of Ghadimi et al. (2013) exceeding the average annual concentration of $\mathrm{SO}_{4}{ }^{2-}$ and $\mathrm{Na}^{+}$in all three studied watersheds. Even average concentrations by Moore and Attar (2011) are unreliable since the share of the precipitation input exceeds solute concentrations in 53-94\% of samples for $\mathrm{SO}_{4}{ }^{2-}, 24-93 \%$ of samples for $\mathrm{Na}^{+}$and $37-45 \%$ of samples for $\mathrm{K}^{+}$in the studied subwatersheds. In contrast, the minimum ion concentration in rainwater from the data of Moore and Attar (2011) are at least 1.5-times lower than that of Ghadimi et al. (2013) and seems to be the most reliable for use in the study area. These data suggest that the highest contributions by rainwater can be expected for $\mathrm{SO}_{4}{ }^{2-}(16 \%), \mathrm{Na}^{+}(23 \%), \mathrm{Cl}^{-}(7 \%), \mathrm{K}^{+}(3 \%)$, and $\mathrm{Ca}^{2+}(2 \%)$ (all other ions $\left.<1 \%\right)$ indicating seawater $\left(\mathrm{SO}_{4}^{2-}, \mathrm{K}^{+}, \mathrm{Na}^{+}, \mathrm{Cl}^{-}\right)$and aeolian dust (calcite, gypsum, halite) as the most plausible sources. Awadh (2012) found that the western Sahara wind (locally known as simoom) that also affects West Asia mostly comprises quartz (49.0\%), calcite (35.6\%), feldspar (5.0\%) and gypsum $(4.9 \%)$ while it is poor in dolomite $(2.42 \%)$, indicating this area as a possible dust source. Differences in precipitation input shares between watersheds show slightly higher share of $\mathrm{Na}^{+}$ 
and $\mathrm{Cl}^{-}$in precipitation in Alashtar and Biranshahr indicating higher halite aeolian sources and higher share of $\mathrm{SO}_{4}{ }^{2-}$ in Khorram Abad. The highest non-precipitation contribution to solute load is calculated to be for $\left(\mathrm{HCO}_{3}^{-}+\mathrm{CO}_{3}{ }^{2-}\right)$ that is primarily related to dissolution of carbonates (carbonate karst denudation).

During all samplings, equilibrium water $\mathrm{pCO}_{2}$ was constantly above atmospheric concentration ( $\left.\sim 400 \mathrm{ppm}\right)$ with an average of $10,890 \mathrm{ppm}$ indicating $\mathrm{CO}_{2}$ outgassing from the water into the atmosphere. Positive $\mathrm{SI}_{\text {Cal }}(76 \%$ of samples) indicates even higher original $p \mathrm{CO}_{2}$ before $\mathrm{CO}_{2}$ outgassing started; since $p \mathrm{CO}_{2}$ shows no seasonality, high initial $\mathrm{CO}_{2}$ concentration is most likely related to the underground karst system and less to biogenic production in surface streams. Only one sample was found to have $\mathrm{SI}_{\text {cal }}$ higher than 1 (rough threshold for calcite precipitation, based on Dreybrodt, 1988) indicating a low likelihood of calcite precipitation (downstream decline of $\mathrm{Ca}^{2+}$ as well as $\mathrm{HCO}_{3}{ }^{-}$and $\mathrm{CO}_{3}{ }^{2-}$ ).

Anthropogenic inputs to solute load are unknown due to an absence of reliable data; one could expect an anthropogenically-induced increase of $\mathrm{K}^{+}$, especially in Alashtar subwatershed due to intensive agriculture in the WS-central part of the basin. While the highest original $p \mathrm{CO}_{2}$ concentration $(15,136 \mathrm{ppm})$ indicates natural processes in the Biranshahr subwatershed, anthropogenic $\mathrm{CO}_{2}$ sources (agriculture, waste water) are plausible in the Khorram Abad (equilibrium $\mathrm{pCO}_{2}$ max 69,183 ppm, 5 samples above 50,000 ppm) and the Alashtar subwatershed (equilibrium $p \mathrm{CO}_{2}$ max 69,183 ppm, 2 samples above 50,000 ppm). However, anthropogenic inputs are expected to be relatively low due to the weak or absent negative correlation between contaminant concentrations and discharge (Table 2) that would be expected due to a dilution effect.

\section{Solute load and ion-exchange process}

While the highest values of Pearson's correlation coefficients (from +0.57 to +0.59 ) are found between $\mathrm{Ca}^{2+}$ and $\mathrm{HCO}_{3}{ }^{-}$for all subwatersheds (Table 2), other correlation coefficients between ionic species are surprisingly low, sometimes negative, and often lack significance even between common ion-pairs (e.g. $\mathrm{Na}^{+}-\mathrm{Cl}^{-}, \mathrm{Mg}^{2+}-\mathrm{HCO}_{3}{ }^{-}, \mathrm{Ca}^{2+}-\mathrm{Mg}^{2+}$ ), indicating the importance of lithologies other than limestone, as well as complex and heterogeneous interactions in the weathering zone.

The average $\mathrm{Na}^{+} / \mathrm{Cl}^{-}$molar ratios are low but similar: $0.53,0.60$ and 0.61 for Alashtar, Khorram Abad, and Biranshahr subwatershed, respectively. Low $\mathrm{Na}^{+} / \mathrm{Cl}^{-}$molar ratios seem to be typical for the Alashtar and Khorram Abad subwatershed (Ahmadipour, 1999) as well as for SW Iran (Adinehvand and Raeisi, 2018). The much lower annual solute flux of $\mathrm{Na}^{+}$compared to $\mathrm{Cl}^{-}$(0.49:1, 0.39:1, 0.49:1 for Alashtar, Khorram Abad, and Biranshahr watershed, respectively) indicates a relatively weak effect of the weathering of $\mathrm{Na}$-bearing minerals, strong $\mathrm{Na}^{+}$-prevailing modification of evaporated seawater from east Mediterranean seawater in precipitation $\left(\mathrm{Na}^{+} / \mathrm{Cl}^{-}\right.$molar ratio of 0.86$)$, low impact of solutes in precipitation (average $\mathrm{Na}^{+} / \mathrm{Cl}^{-}$molar ratio above 0.88; Moore and Attar, 2011; Ghadimi et al., 2013), and/or possible, but less likely, anthropogenic $\mathrm{Cl}^{-}$sources such as coal combustion, waste incineration, or sea-salt dechlorination (Thimonier et al., 2008). The $\mathrm{Na}^{+} / \mathrm{Cl}^{-}$molar ratio is also very different from that in Lake Urmia, the biggest nearby salt lake located $550 \mathrm{~km}$ northwest (0.86; Alipour, 2006), with a tendency toward the low values found in some other lakes, such as the Dead Sea (0.28). The very high standard deviations of average $\mathrm{Na}^{+} / \mathrm{Cl}^{+}$molar ratios $( \pm 0.41, \pm 0.29$, \pm 0.44 ) with a relatively high annual coefficient of variation of $\mathrm{Na}^{+}$concentrations compared to $\mathrm{Cl}^{-}$concentrations indicates $\mathrm{Na}^{+}$adsorption and desorption during ion-exchange reactions in the weathering zone. This idea is supported by a negative correlation between the $\mathrm{Na}^{+} / \mathrm{Cl}^{-}$molar ratio and $\mathrm{Cl}^{-}$concentration as has been found to be indicative for soil adsorption by Neal and Kircher (2000). The Chloro-Alkali Index (CAl; $\left[\mathrm{Cl}^{-}-\left(\mathrm{Na}^{+}+\mathrm{K}^{+}\right)\right] /\left[\mathrm{Cl}^{-}\right]$; in meq $\left.\mathrm{L}^{-1}\right)$ and Chloro-Alkali Index $2\left(\mathrm{CAl} 2\right.$; $\left[\mathrm{Cl}^{-}-\left(\mathrm{Na}^{+}+\mathrm{K}^{+}\right)\right] /\left[\mathrm{SO}_{4}{ }^{2-}+\mathrm{HCO}_{3}^{-}\right]$; in meq $\left.{ }^{-1}\right)$, which are often used as indicators of ion-exchange processes (Schoeller, 1977; Hussien and Faiyad, 2016), are positive on average at the subwatershed scale $(0.32<\mathrm{CAl}<0.5 ; 0.04<\mathrm{CAl} 2<0.15)$ suggesting higher $\mathrm{Na}^{+}$and $\mathrm{K}^{+}$release into the groundwater compared to $\mathrm{Ca}^{2+}$ and $\mathrm{Mg}^{2+}$ during ion-exchange processes. Pearson's correlation of CAl and CAI2 with discharge is weakly positive $(+0.19,+0.13$, and +0.17 for Alashtar, Khorram Abad, and Biranshahr, respectively) but negative when restricted to low discharges (Fig. 7A) indicating $\mathrm{Na}^{+}$and $\mathrm{K}^{+}$desorption during low discharge, when $\mathrm{Mg}^{2+}$ as well as $\mathrm{Ca}^{2+}$ should

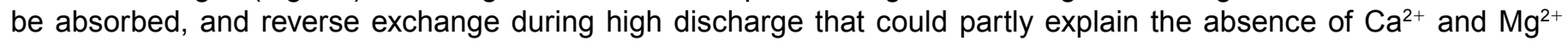
decrease due to dilution during high discharge (Fig. 4A where $\mathrm{Ca}^{2+}$ and $\mathrm{Mg}^{2+}$ are considered as the main constituents of total solute load). Among the studied watersheds, especially CAI indicates several-months-long high values with short intervals of low (slightly negative) values (Fig. 7B). Beside the conservative ion $\mathrm{Cl}^{-}$, the main factor especially for $\mathrm{CAl}$ is $\mathrm{Na}^{+}$(and not $\mathrm{K}^{+}$) suggesting that $\mathrm{Na}^{+}$is the most susceptible monovalent cation during ion exchange, which is consistent with $\mathrm{Mg}^{2+}$ when compared with $\mathrm{K}^{+}$or $\mathrm{Na}^{+}$. While the relationship between of $\mathrm{Mg}^{2+}$ and $\mathrm{K}^{+}$shows a positive correlation, the relation of $\mathrm{Mg}^{2+}$ with $\mathrm{Na}^{+}$is negative indicating cation exchange between $\mathrm{Mg}^{2+}$ and $\mathrm{K}^{+}$with $\mathrm{Na}^{+}$. Similar negative correlation between $\mathrm{Na}^{+}$and $\mathrm{Mg}^{2+}$ in all three watersheds (Table 2) suggests that the main cation exchange occurs between these two species due to a similar tendency for adsorption. Adsorption is indicated by the coefficient of variation that increases from strongly absorbed $\mathrm{Ca}^{2+}(0.19-0.35)$ over moderately absorbed $\mathrm{Mg}^{2+}(0.39-0.54)$ to weakly absorbed $\mathrm{Na}^{+}(0.54-0.94)$ and $\mathrm{K}^{+}(0.82-1.18)$; as a rule, the $\mathrm{Mg}^{2+} / \mathrm{Na}^{+}$molar ratio also increases with discharge. Due to 

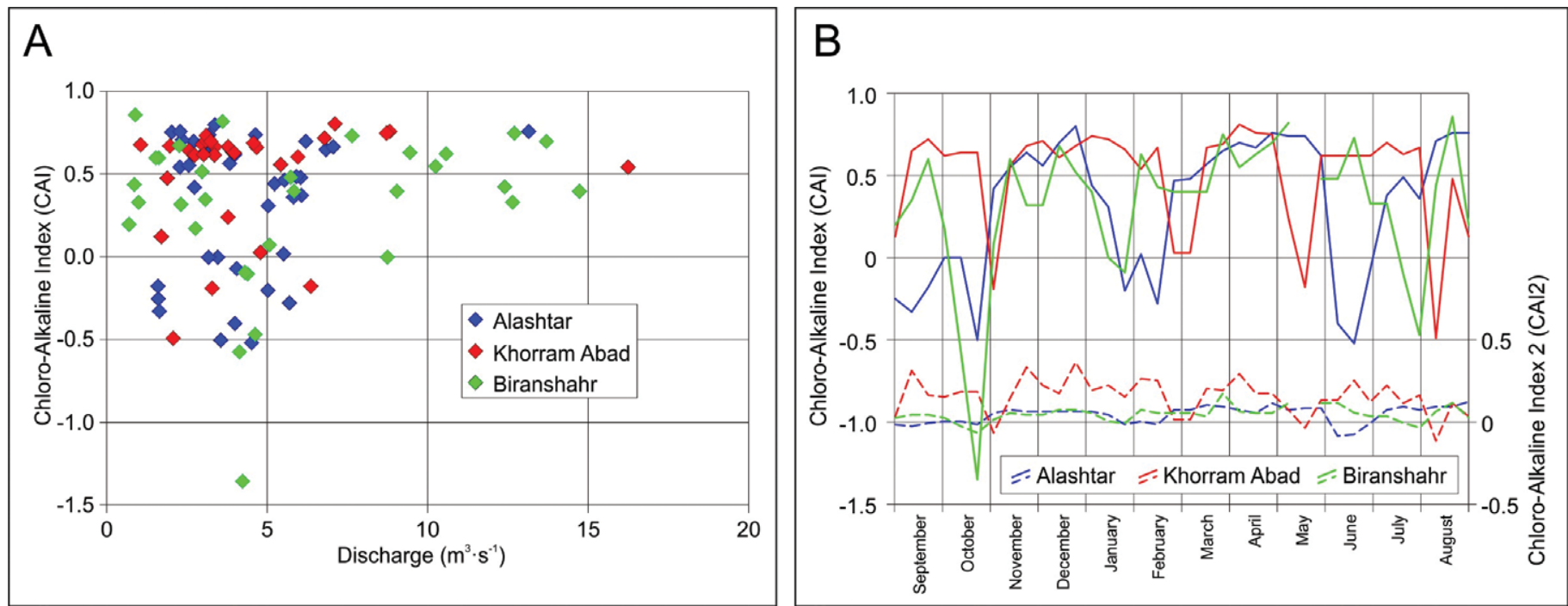

Figure 7. Correlation of $(\mathrm{A})$ Chloro-Alkaline Index (CAI) with discharge and (B) seasonal pattern of both indexes (CAI - full line; CAI2 dashed line).

$\mathrm{Na}^{+}$sorption and desorption, Pearson's correlation between $\mathrm{Na}^{+}$and $\mathrm{Cl}^{-}$is much lower (Table 2) than expected solely from halite dissolution.

\section{Solutional and carbonate karst denudation rate}

The solutional load is the quantity of bedrock leaving the catchment area in solution due to chemical weathering and precipitation input, assuming that ion-exchange sorption and desorption are balanced during a year of observation. The solute flux, expressed as average annual material loss per area, was found to be the highest in Alashtar $\left(69 \mathrm{t} \mathrm{km}^{-2} \mathrm{a}^{-1}\right)$, followed by Biranshahr $\left(54 \mathrm{t} \mathrm{km}^{-2} \mathrm{a}^{-1}\right)$ and Khorram Abad $\left(49 \mathrm{t} \mathrm{km}^{-2} \mathrm{a}^{-1}\right)$. The highest impact on differences is from the alkalinity and concentration of $\mathrm{Ca}^{2+}$. A decrease of solutional load trends from NW to SE that might indicate a climatic effect as a result of different altitudes (Fig. 2). The same decrease was found for carbonate karst dissolution rates calculated for all possible carbonate outcrops $\left(L+D+M+Q ; r^{2}=0.81, p=0.13\right.$; Table 3$)$ but is not significant $(p<0.05)$ without an additional subwatershed.

As already described, by far the highest solute flux of $\mathrm{Ca}^{2+}, \mathrm{Mg}^{2+}$ and $\mathrm{HCO}_{3}^{-}$is from limestone and dolomite, and is much less for gypsum (12-14\%), while the precipitation input of $\mathrm{Ca}^{2+}(2 \%)$ and $\mathrm{Mg}^{2+}(<1 \%)$ can be neglected. Carbonate karst dissolution rates calculated per area strongly depend on the area of carbonate outcrops in each subwatershed (Table 3); since carbonate dissolution certainly takes place on limestones and dolomites, the presence of areas of marls and Quaternary deposits can have an opposite role and dilute the solute flux from the carbonate rocks. While thin and not substantially eluviated regolith on marls can provide even higher water hardness than limestone or dolomite massifs, especially during low water levels (Gams, 1966), accumulation of thick regolith and leaching on a geological timescale can stimulate surface runoff and substantially reduce chemical interaction with marls. Dissolution rates of Quaternary deposits mostly depend on carbonate content, prior leaching, as well as thickness of regolith. On the contrary, weathering of extensive outcrops of allogenic rocks can provide $\mathrm{Ca}^{2+}$ and $\mathrm{Mg}^{2+}$ ions at the contact with carbonates due to highly aggressive allogenic water (Lauritzen, 1990; Gabrovšek, 2009); the latter situation can increase denudation rates up to $203 \mathrm{~m}^{3} \mathrm{~km}^{-2} \mathrm{a}^{-1}$ as shown by a study of an area of $0.0362 \mathrm{~km}^{2}$ of marble-striped karst affected by sulfate waters in the Polish Sudetes Mountains (Rzonca and Buczyński, 2013) or more than $50 \mathrm{~m}^{3} \mathrm{~km}^{-2} \mathrm{a}^{-1}$ in SW Spitsbergen (Pulina et al., 1984). To ensure reliable comparison, despite year-to-year fluctuations, our results have been compared only with results derived using a similar hydrochemical approach (Table 5) since at least part of endokarst dissolution is absent using MEM or limestone tablets, and fluctuation of dissolution rates on geological time scales should be taken into account when results of a measured thickness of dissolved carbonate divided by age (e.g., post-glacial formation of limestone pedestals) are used (Gams, 1985; Plan, 2005; Häuselmann, 2008; Gabrovšek, 2009). Despite a 3-fold difference in the areas over which dissolution has been calculated $\left(0.010-0.040 \mathrm{~mm} \mathrm{CaCO}_{3}\right.$ $\mathrm{a}^{-1}$ or $10-40 \mathrm{~m}^{3}$ as $\mathrm{CaCO}_{3} \mathrm{~km}^{-2} \mathrm{a}^{-1}$ including the dissolution of gypsum), carbonate karst dissolution rates at Alashtar, Khorram Abad, and Biranshahr subwatersheds are similar to those found on slightly elevated karst plateaus in Central Europe with warm and humid summer continental climate (e.g., SW Poland according to Pulina, 1974, 1977) and on the bare karst of northern Norway, but less than in the mountainous areas of the Alps, Pyrenees, Tatras, and Dinaric mountains. 
Table 5. Comparison of carbonate karst dissolution rates calculated by a hydrochemical approach.

\begin{tabular}{|c|c|c|}
\hline $\begin{array}{l}\text { Carbonate Denudation } \\
\text { Rate }\left(\mathrm{m}^{3} \mathrm{~km}^{-2} \mathrm{a}^{-1}\right)\end{array}$ & Region (comment) & Source \\
\hline $10-40$ & Alashtar, Khorram Abad, Biranshahr subwatershed, Iran (491-754 mm a-1) & This study \\
\hline $4-35$ & Svalbard, Norway (bare karst) & Krawczyk, 2008 \\
\hline $20.5-33$ & Sudetes karst, Poland & Pulina, 1977 \\
\hline $32.5 \pm 10.2$ & Northern Norway (bare karst; 2,600 mm precipitation $\mathrm{a}^{-1}$ ) & Lauritzen, 1990 \\
\hline $48-89$ & Baget karst system, Pyrenees, France (5-years-long study) & Bakalowicz, 1979 \\
\hline $60-70$ & Classical Karst, Slovenia & Gams, 1966 \\
\hline $90-100$ & Alpine Karst, Slovenia & Gams, 1966 \\
\hline $61-88$ & Waitomo, New Zealand & Gunn, 1981 \\
\hline 82 & Kościeliski Creek, Western Tatra Mountains, Poland & Barzyk, 1998 \\
\hline
\end{tabular}

The excellent connection between water and solute runoff (Fig. 4B), where $\mathrm{Ca}^{2+}$ and $\mathrm{Mg}^{2+}$ are responsible for $80-90 \%$ of solute runoff, indicates a primary role of water runoff on solute runoff, as well as on carbonate karst dissolution rate in all studied subwatersheds. The relation is linear and is consistent with previous observations where solute runoff was compared with discharge (Julian et al., 1978; Pulina et al., 1984) or where yearly dissolution rate was compared with yearly runoff (Gabrovšek, 2009) in selected catchments despite the fact that other climatic (temperature, $\mathrm{CO}_{2}$ concentration) and lithologic factors could affect the seasonality of carbonate karst denudation rate. Pulina et al. (1984) observed a (quasi)logarithmic relationship between stream discharge and solute load in the calcite undersaturated waters of Spitsbergen. Residuals between measured and runoff-based calculated karst dissolution rates (according to trend lines in Fig. 4B) do not show seasonal patterns that are often thought to be a result of dissolution-related factors (temperature, $\mathrm{CO}_{2}$ production). An absence of lower solute concentration during high discharge (Fig. 4B) shows a negligible effect of dilution during flood events, as was found at some karst springs in the Zagros Mts. (Mohammadi and Field, 2009) and interpreted to be a result of a large underground aquifer and/or small non-rapid recharge component.

\section{Solute load vs. suspended load}

Determination of suspended load based on occasional sampling makes possible a comparison of solute load with suspended load. While solute load varies between 195 and $429 \mathrm{mg} \mathrm{L}^{-1}$ (avg. $=330 \mathrm{mg} \mathrm{L}^{-1}$ ), 276 and $727 \mathrm{mg} \mathrm{L}^{-1}$ (avg. $=$ $472 \mathrm{mg} \mathrm{L}^{-1}$ ), and 222 and $510 \mathrm{mg} \mathrm{L}^{-1}$ (avg. $=313 \mathrm{mg} \mathrm{L}^{-1}$ ) in Alashtar, Khorram Abad, and Biranshahr subwatershed, respectively, suspended load is approximately one magnitude lower at $10-119 \mathrm{mg} \mathrm{L}^{-1}$ (avg. $=46 \mathrm{mg} \mathrm{L}^{-1}$ ), 6-1,217 mg L-1 (avg. $=127 \mathrm{mg} \mathrm{L}^{-1}$ ), and $7-155 \mathrm{mg} \mathrm{L}^{-1}\left(\right.$ avg. $=41 \mathrm{mg} \mathrm{L}^{-1}$ ). The only case where the suspended load was higher than the solute load was at the beginning of February 2015 (Khorram Abad; 3-times higher than the solute load), when the highest discharge was recorded during sampling (4-times the average discharge). As a result, the ratio between solute and suspended load is high; on average 1:0.14, 1:0.30, and 1:0.13 in Alashtar, Khorram Abad, and Biranshahr subwatershed, respectively. The correlation between discharge and suspended load is negligible and not significant $(r=-0.02 ; p=0.97)$ as between discharge and solute load in Alashtar, moderate and significant in Biranshahr $(r=+0.52 ; p<0.05)$, and much higher and significant in the case of Khorram Abad $(r=+0.80 ; p<0.05)$ where the aforementioned flood event, with exceptionally high suspended load of $1,217 \mathrm{mg} \mathrm{L}^{-1}$ had a large effect. During this flood event, the concentration of suspended sediment was higher than the sum of all concentrations in 28 other samples, showing an important role of flash floods for the mobilization of fine-grained sediment. According to the ratios between the annual solute and the suspended loads calculated as tonnes per sampling period, the solute load comprises $88 \%$, $66 \%$, and $85 \%$ of solute+suspended load in Alashtar, Khorram Abad, and Biranshahr, respectively. If we assume that bed load represents 0.2-0.6 \% in the case of Karkheh River (Hassanzadeh et al., 2011), the solution load is responsible for the majority of measured overall (mechanical+chemical) denudation. Except during very high discharge, when more intensive mobilization of suspended and bed load is expected, while solute load is expected to be more stable, dissolution is recognized as the crucial process of surface denudation.

\section{CONCLUSIONS}

The main process affecting the composition of surface water in the study area is carbonate dissolution, contributing three abundant species: $\mathrm{HCO}_{3}^{-}, \mathrm{Ca}^{2+}$ and $\mathrm{Mg}^{2+}$. The fourth most abundant ion $\left(\mathrm{Cl}^{+}\right)$could indicate dissolution of halite that should influence the concentration of $\mathrm{Na}^{+}$too. However, the concentration of $\mathrm{Na}^{+}$is much less than $\mathrm{Cl}^{+}$, and is annually highly variable and controlled by ion-exchange processes probably in the regolith. As a result, correlations between $\mathrm{Cl}^{-}$and $\mathrm{Na}^{+}$concentrations is low in all three subwatersheds. Very low average concentration of $\mathrm{Na}^{+} \mathrm{com}-$ pared to $\mathrm{Cl}^{+}$as well as annual flux of the $\mathrm{Na}^{+} / \mathrm{Cl}^{-}$ratio indicates very weak weathering of Na-bearing minerals, a strong 
modification of evaporated seawater from the east Mediterranean Sea in precipitation, or low impact of solutes in precipitation, and/or possible, but less likely, anthropogenic $\mathrm{Cl}^{-}$sources.

No obvious seasonal pattern (except for $\mathrm{Na}^{+}$) and extremely weak correlation of analyzed species with discharge show multiple and complex processes within the heterogeneous lithology of the studied catchment areas. Due to fairly good average negative Pearson's correlations, that is significant in the case of Alashtar subwatershed, it seems that during ion exchange $\mathrm{Na}^{+}$substitutes mainly for $\mathrm{Mg}^{2+}$. This can to some extent explain the lack of $\mathrm{Mg}^{2+}$ variation during flood events when $\mathrm{Mg}^{2+}$ can be substituted in the ion-exchange process with $\mathrm{Na}^{+}$while the process is opposite during low discharges.

Despite the fact that carbonate karst denudation rates calculated from hydrochemical data are faced with several problems (e.g., delineation of carbonate outcrops, the possibility that sulfate rocks contribute to $\mathrm{Ca}^{2+}$ and $\mathrm{Mg}^{2+}$ fluxes, and a role for carbonate dissolution by allogenic waters with $\mathrm{SI}_{\mathrm{Cal} / \mathrm{Dol}}<<0$ ), it is still an appropriate method for obtaining a first-order estimate of solutional denudation (Ford and Williams, 2007). Since there is negligible input of $\mathrm{Ca}^{2+}$ and $\mathrm{Mg}^{2+}$ (from 2 to $<1 \%$ ) from precipitation as well as $\mathrm{Ca}^{2+}$ due to dissolution of gypsum (11-13\%), the calculation of carbonate karst dissolution rates was possible and found to be from 10 to $40 \mathrm{~m}^{3} \mathrm{~km}^{-2} \mathrm{a}^{-1}$. Since solute flux is strongly determined by discharge, which was $27-37 \%$ lower than the 30-year-long average during the measurement period due to relatively small runoff probably caused by higher evapotranspiration rates, higher dissolution rates are expected over long periods. Due to 11.9-28.2 \% share of subwatersheds being underlain by marl, that can enhance or hinder carbonate dissolution, the calculated differences between subwatersheds are not reliable. Since solute and carbonate fluxes mainly depend on discharge, solutional carbonate karst denudation rates strongly depend on floods: one event detected over $\sim 10$ days of sampling contributed up to $8-11 \%$ of the annual denudation rate while during low discharge the denudation was 10 -times below the average.

Comparison between suspended and solute loads shows generally much higher solute load indicating that dissolution is the controlling process for surface denudation. However, the solute load is 3-times lower during flash flood events due to the mobilization of large amounts of fine-grained sediment that reverses this relationship.

No major hydrochemical differences were detected between the three subwatersheds. However, a small decrease in both the solute flux from NW to SE and carbonate karst dissolution rates calculated for all possible carbonate outcrops $(L+D+M+Q)$ might indicate a climatic effect as a result of different altitudes of the subwatersheds.

\section{ACKNOWLEDGEMENTS}

We thank the laboratory at the Natural Resources Faculty of Tehran University and the Iran National Science Foundation (INSF) for supporting this study (Project Code: 93038031) and the Slovenian Research Agency (P6-0119 Karst Research Programme) for the possibility to evaluate gathered data. Authors appreciate comments by Augusto Auler and another anonymous reviewer that improved the quality of this paper.

\section{REFERENCES}

Abu-Jaber, N., Hess, J.W., and Howcroft, W., 2001, Chemical erosion of the Lilburn Cave system, Kings Canyon National Park, California: Ground Water, v. 39, no. 2, p. 223-229. https://doi.org/10.1111/j.1745-6584.2001.tb02303.x.

Adinehvand, R., and Raeisi E., 2018, Characterization of a karst aquifer in a complex tectonic region, Southwestern Iran: Journal of Cave and Karst Studies, v. 80, no. 4, p. 190-205. https://doi.org/10.1111/j.1745-6584.2001.tb02303.x.

Aghanabati, A., 2004, Geology of Iran: Geological Survey \& Mineral Explorations of Iran (GSI), v. 1, 640 p.

Ahmadipour, M.R., 1999, Karst terraines in Iran - Examples from Lorestan: Acta Carsologica, v. 28, no. 2, p. 213-224. https://doi.org/10.3986/ ac.v28i2.494

Ahmadipour, M.R. 2003, Karst Springs of Alashtar, Iran: Acta Carsologica, v. 32, no. 2, p. 244-254. https://doi.org/10.3986/ac.v32i2.352.

Alipour, S., 2006, Hydrogeochemistry of seasonal variation of Urmia Salt Lake, Iran: Saline Systems, v. 2, no. 9. https://doi.org/10.1186/17461448-2-9.

Awadh, S.M., 2012, Geochemistry and mineralogical composition of the airborne particles of sand dunes and dust storms settled in Iraq and their environmental impacts. Environmental Earth Sciences, v. 66 no. 8, p. 2247-2256. https://doi.org/10.1007/s12665-011-1445-6.

Bahroudi, A., and Koyi, H., 2004, Tectono-sedimentary framework of the Gachsaran Formation in the Zagros foreland basin: Marine and Petroleum Geology, v. 21, p. 1295-1310. https://doi.org/10.1016/j.marpetgeo.2004.09.001.

Bakalowicz, M., 1979, Contribution de la geochimie des eaux à la connaissance de l'aquifère karstique et de la karstification, [Ph.D. Dissertation]: Univ. Paris-6, 269 p.

Barczyk, G., 1998, Denudacja chemiczna krasu węglanowego w świetle badań stacjonarnych zlewni potoków Chocho łowskiego i Ko ścieliskiego (Tatry Zachodnie) [Chemical denudation of carbonate karst in the catchments of Chocho łowski and Ko ścieliski Creeks based on research using stationary measurement stations (the western Tatra Mountains)]: Kras i speleologia, v. 18, no. 9, p. 223-233.

Barmaki, M.D., Rezaei, M., Raeisi, E., and Ashjari, J., 2019, Comparison of surface and interior karst development in Zagros Karst Aquifers, Southwest Iran: Journal of Cave and Karst Studies, v. 81, no. 2, p. 84-97. https://doi.org/10.4311/2017ES0120.

Borelli, L., Greco, R., and Gulia, G., 2007, Weathering grade of rock masses as a predisposing factor to slope instabilities: reconnaissance and control procedures: Geomorphology, v. 87, no. 3, p. 158-175. https://doi.org/10.1016/j.geomorph.2006.03.031.

Bosak, P., Jaroš, J., Spudil, J., Sulovsky, P., Václavek, V., 1998, Salt Plugs in the Eastern Zagros, Iran: Results of Regional Geological Reconnaissance: GeoLines, v. 7, p. 3-174.

Chesworth, W., 2008, Encyclopedia of Soil Science: Springer, Dordecht, 902 p. https://doi.org/10.1007/978-1-4020-3995-9. 
Chow, V.T., Maidment, D.R., Mays, L.W., 2007, Applied hydrology: McGraw-Hill, New York, 588 p.

Cucchi, F., and Zini L., 2003, Gypsum karst of Zagros Mountains (I.R. Iran): Acta Carsologica, v. 32, no. 1, p. 69-82. https://doi.org/10.3986/ ac.v32i1.365.

Dixon, J., Thorn, C., 2005, Chemical weathering and landscape development in midlatitude alpine environments: Geomorphology, v. 67, no. 1-2, p. 127-145. https://doi.org/10.1016/j.geomorph.2004.07.009.

Dreybrodt, W., 1988, Processes in Karst Systems (Physics, Chemistry, and Geology): Springer-Verlag, Berlin-Heidelberg-New York-London-Paris-Tokyo, $288 \mathrm{p}$.

Ford, D.C., and Williams, P.W., 2007, Karst Geomorphology and Hydrology: John Wiley \& Sons, Chichester, 562 p.

Gabrovšek. F., 2007, On denudation rates in karst: Acta Carsologica, v. 36, no. 1, p. 7-13. https://doi.org/10.3986/ac.v36i1.203.

Gabrovšek, F., 2009, On concepts and methods for the estimation of dissolutional denudation rates in karst areas: Geomorphology, v. 106, no. 1-2, p. 9-14. 10.1016/j.geomorph.2008.09.008

Gams, I., 1966, Faktorji in dinamika korozije na karbonatnih kameninah slovenskega dinarskega in alpskega krasa. [Factors and dynamics of corrosion of the carbonaticr Rocks in the Dinaric and Alpine Karst of Slovenia (Yugoslavia)]: Geografski vestnik, v. 38, p. 11-68.

Gams, I., 1985, Mednarodne primerjalne meritve površinske korozije s pomočjo standardnih apneniških tablet [International comparative measurements of surface solution by means of standard limestone tablets], Razprave IV: Razreda, v. 26, p. 361-388.

Ghadimi, F., Ghomi, M., Ranjbar, M., and Hajati, A., 2013, Sources of contamination in rainwater by major and heavy elements in Arak, Iran: Journal of Water Sciences Research, v. 5, no. 2, p. 67-82.

Goldscheider, N., Chen, Z., Auler, A.S., Bakalowicz, M., Broda, S., Drew, D., Hartmann, J., Jiang, G., Moosdorf, N., Stevanovic, Z., Veni, G., 2020, Global distribution of carbonate rocks and karst water resources: Hydrogeology Journal. https://doi.org/10.1007/s10040-020-02139-5.

Gunn, J., 1981, Limestone solution rates and processes in the Waitomo district, New Zealand: Earth Surface Processes and Landforms, no. 6, v. 5, p. 427-445. https://doi.org/10.1002/esp.3290060504

Hassanzadeh, H., Faiznia, S., Shafai Bajestan, M., and Motamed, A., 2011, Estimate of Sediment Transport Rate at Karkheh River in Iran Using Selected Transport Formulas: World Applied Sciences Journal, v. 13, no. 2, p. 376-384.

Häuselmann, P., 2008, Surface corrosion of an Alpine karren field: recent measures at Innerbergli (Siebenhengste, Switzerland): International Journal of Speleology, v. 37, no. 2, p. 107-111. https://doi.org/10.1002/esp.3290060504.

Heimsath, A.M., Dietrich, W.E., Nishiizumi, K., and Finkel, R.C., 1997, The soil production function and landscape equilibrium: Nature, v. 388 , p. 358-361. https://doi.org/10.1038/41056.

Hussien, B.M., and Faiyad, A.S., 2016, Modeling the Hydrogeochemical Processes and Source of lons in the Groundwater of Aquifers within KasraNukhaib Region (West Iraq): International Journal of Geosciences, v. 7, no. 10, p. 1156-1181. http://doi.org/10.4236/ijg.2016.710087.

Julian, M., Martin, J., and Nicod, J., 1978, Les karsts Mediterraneens: Mediterranee, v. 32, no. 1-2, p. 115-131. https://doi.org/10.3406/medit.1978.1775.

Kaufmann, G., and Dreybrodt, W., 2007, Calcite dissolution kinetics in the system $\mathrm{CaCO}_{3}-\mathrm{H}_{2} \mathrm{O}-\mathrm{CaCO}_{3}$ at high undersaturation: Geochimica et Cosmochimica Acta, v. 71, no. 6, p. 1398-1410. https://doi.org/10.1016/j.gca.2006.10.024.

Kieffer, B., Jové, C.F., Oelkers, E.H., and Schott, J., 1999, An experimental study of the reactive surface area of the Fontainebleau sandstone as a function of porosity, permeability, and fluid flow: Geochimica et Cosmochimica Acta, v. 63, no. 21, p. 3525-3534. https://doi.org/10.1016/ S0016-7037(99)00191-X.

Krautblatter, M., and Moore J.R., 2014, Rock slope instability and erosion: toward improved process understanding: Earth Surface Processes and Landforms, v. 39, no. 9, p. 1273-1278. https://doi.org/10.1002/esp.3578.

Krawczyk, W.E., 2008, The range of chemical denudation rates on Svalbard, in Geophysical Research Abstracts 10, EGU General Assembly 2008.

Krawczyk, W.E., Lefauconnier, B., and Pettersson, L.-E., 2003, Chemical denudation rates in the Bayelva Catchment, Svalbard, in the Fall of 2000: Physics and Chemistry of the Earth Parts A/B/C, v. 28, no. 28-32 p. 1257-1271. https://doi.org/10.1016/j.pce.2003.08.054.

Krklec, K., Villar, D., Carrasco, R.M., and Pedraza, J., 2016, Current denudation rates in dolostone karst from central Spain: Implications for the formation of unroofed caves: Geomorphology, v. 264, p. 1-11. https://doi.org/10.1016/j.geomorph.2016.04.007.

Lauritzen, S.-E., 1990, Autogenic and allogenic denudation in carbonate karst by the multiple basin method-an example from Svartisen, north Norway: Earth Surface Processes and Landforms, v. 15, no. 2, p. 157-167.

Lauritzen, S.-E., 2005, A simple growth model for allogenic Karrentische, in Final Programme \& Abstract Book, Proceedings of the $14^{\text {th }}$ International Congress of Speleology, $21^{\text {th }}-28^{\text {th }}$ August 2005, Athens-Kalamos, Greece.

Maire, R., 1981, Karst and hydrogeology synthesis: Spelunca, no. 3, p. 23-30.

Matsushi, Y., Sasa, K., Takahashi, T., Sueki, K., Nagashima, Y., and Matsukura, Y., 2010, Denudation rates of carbonate pinnacles in Japanese karst areas: Estimates from cosmogenic ${ }^{36} \mathrm{Cl}$ in calcite: Nuclear Instruments and Methods, v. 268, no. 7-8, p. 1205-1208. https://doi. org/10.1016/j.nimb.2009.10.134.

Minasny, B., McBratney, A.B., and Salvador-Blanes, S., 2008, Quantitative models for pedogenesis - a review: Geoderma, v. 144, no. 1, p. 140-157. https://doi.org/10.1016/j.geoderma.2007.12.013.

Mohammadi, Z., and Field, M.S., 2009, On the Temporal Behavior of Karst Aquifers, zagros Region, Iran: A Geostatistical Approach: Journal of Cave and Karst Studies, v. 71, no. 3, p. 210-226. https://doi.org/10.4311/jcks2009es0079.

Molina Ballesteros, E., Garcia-Talegon, J., Herrero Fernandez, H., and Inigo, A.C., 2013, Changes of porosity due to weathering in quartzites and slates of a Rana profile (Montes de Toledo, Central Spain): Estudios Geológicos, v. 69, no. 2, p. 179-191. https://doi.org/10.3989/ egeol.41185.252.

Moore, F., and Attar, A., 2011, Rainwater and the resulting runoff chemistry in Shiraz city, southwest Iran: International Journal of Environmental Studies, v. 68, no. 5, p. 703-717. https://doi.org/10.1080/00207233.2011.591898.

Mortazavi, M., Heuss-Assbichler, S., and Shahri, M., 2017, Hydrothermal systems in the salt domes of south Iran: Procedia Earth and Planetary Science, v. 17, p. 913-916. https://doi.org/10.1016/j.proeps.2017.01.016.

Nabavi, M.H., 1976, An introduction to geology of Iran: Geological Survey \& Mineral Explorations of Iran (GSI), 109 p.

Neal, C., and Kirchner, J.W., 2000, Sodium and chloride levels in rainfall, mist, streamwater and groundwater at the Plynlimon catchments, mid-Wales: interferences on hydrological and chemical controls: Hydrology and Earth System Sciences, v. 4, no. 2, p. 295-310. https://doi. org/10.5194/hess-4-295-2000

Parkhurst, D.L., and Appelo, C.A.J., 2013, Description of Input and Examples for PHREEQC (Version 3) - A Computer Program for Speciation, Batch-Reaction, One-Dimensional Transport, and Inverse Geochemical Calculations, U.S. Geological Survey Techniques and Methods, Book 6, Chapter A43, 497 p. https://doi.org/10.3133/tm6A43. 
Phillips, J.D., 2005, Weathering instability and landscape evolution: Geomorphology, v. 67, no. 1-2, p. 255-272. https://doi.org/10.1016/j.geomorph.2004.06.012.

Plan, L., 2005, Factors controlling carbonate dissolution rates quantified in a field test in the Austrian Alps: Geomorphology, v. 68, no. 3-4, p. 201-212. https://doi.org/10.1016/j.geomorph.2004.11.014.

Pulina, M., 1974, Denudacja chemiczna na obszarach krasu węglanowego [Chemical denudation in areas of carbonate karst]: Prace geograficzne IG PAN NR 105, p. 1-159.

Pulina, M., 1977, Zjawiska krasowe w Sudetach Polskich [Karst phenomena in the Polish Sudety Mountains]: Dokumentacja Geograficzna PAN, fasc. 2-3, p. 1-118.

Pulina, M., Krawczyk, W., and Pereyma, J., 1984, Water balance and chemical denudation in the unglaciated Fuglebert basin (SW Spitspergen): Polish Polar Research, v. 5, no. 3-4, p. 183-205.

Raeisi, E., 2004, Iran, in Gunn, J., ed., Encyclopedia of Cave and Karst Science, Fitzroy Dearborn, New York, p. $992-995$.

Ryb, U., Matmon, A., Erel, Y., Haviv, I., Benedett,i L., and Hidy, A.J., 2014, Styles and rates of long-term denudation in carbonate terrains under a Mediterranean to hyper-arid climatic gradient: Earth and Planetary Science Letters, v. 406, p. 142-152. https://doi.org/10.1016/j. epsl.2014.09.008.

Rzonca, B., and Buczynski, S., 2013, Intense karst denudation in a crystalline basin with a small share of carbonate rocks (Sudety Mountains, SW Poland): Catena, v. 107, p. 154-164. https://doi.org/10.1016/j.catena.2013.03.003.

Sadeghi, S.H.R., Mizuyama, T., Singh, J.K., and Tofighi, B., 2009, Applicability of Instantaneous Unit Sediment Graph Model in an Iranian Large Watershed: International Journal of Ecological Economics and Statistics, v. 13, no. 9, 30-45.

Sadeghi, S.H.R., and Saeidi, P., 2010, Reliability of Sediment Rating Curves for a Deciduous Forest Watershed in Iran: Hydrological Sciences Journal, v. 55, no. 5, 821-831. https://doi.org/10.1080/02626667.2010.489797.

Schoeller, H., 1977, Geochemistry of Groundwater, in Brown, R.H. et al., eds., Groundwater Studies—An International Guide for Research and Practice, UNESCO, Paris, p. 1-18.

Smith, D.I., and Atkinson, T.C., 1976, Processes, landforms and climate in limestone regions, in Derbyshire, E., ed., Geomorphology and Climate, John Wiley, London, p. 367-409.

Stokes, T., Griffiths, P., and Ramsey, C., 2010, Karst Geomorphology, Hydrology and Management, in Pike, R.G. et al., eds., Compendium of Forest Hydrology and Geomorphology in British Columbia, Land Management Handbook 66, BC Government and FORREX, Government Publications Services, Victoria, p. 373-400.

Thimonier, A., Schmitt, M., Waldner, P., and Schleppi, P., 2008, Seasonality of the $\mathrm{Na} / \mathrm{Cl}$ ratio in precipitation and implications of canopy leaching in validating chemical analyses of throughfall samples: Atmospheric Environment, v. 42, no. 40, p. 9106-9117. https://doi.org/10.1016/j. atmosenv.2008.09.007.

Viles, H.A., 2012, Linking weathering and rock slope instability: nonlinear perspectives: Earth Surface Processes and Landforms, v. 38, no. 1, p. 62-70. https://doi.org/10.1002/esp.3294.

White, W.B., 2000, Dissolution of limestone from field observations, in Klimchouk, A.B. et al., eds. Speleogenesis and Evolution of Karst Aquifers, National Speleological Society, Huntsville, p. 149-155. 